\title{
MITIGATING SALT STRESS EFFECTS BY EXOGENOUS APPLICATION OF PROLINE AND YEAST EXTRACT ON MORPHO- PHYSIOLOGICAL, BIOCHEMICAL AND ANATOMICAL CHARACTERS OF CALENDULA PLANTS
}

\author{
Ghada M.R. El-Shawa*, Eman M. Rashwan ${ }^{* *}$ and Kh. A.A. Abdelaal ${ }^{* * *}$ \\ *Ornamental Plants and Landscape Gardening Research Dept., Hort. Res. Inst., A.R.C., Egypt \\ ${ }^{* *}$ Soil Fertility and Plant Nutrition Research Dept., Soil, Water and Environment Res. Inst., A.R.C., \\ Egypt \\ ${ }^{* * *}$ EPCRS Excellence Center, Plant Pathology and Biotechnology Lab., Agric. Botany Dept., Fac. \\ Agric., Kafrelsheikh Univ., Egypt
}

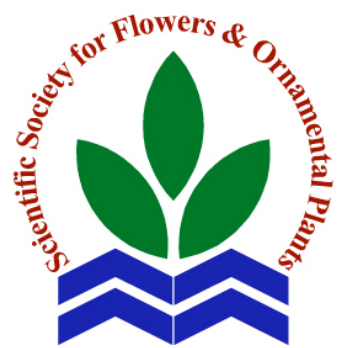

Scientific J. Flowers \& contrary, they decreased $\mathrm{Na} \%$ in the plant. Results showed that Ornamental Plants, 7(4):461-482 (2020).

Received: $13 / 8 / 2020$

Accepted:

$29 / 8 / 2020$ content, carotenoid, total chlorophyll, proline content in plant leaves, as well as the activity of PPO, POX and CAT. Also, the above treatments led to improve calendula plant growth by reducing the activity of both superoxide and hydrogen peroxide and decreasing EL. Application of proline, yeast and their interactions increased the elements content of calendula plant for $\mathrm{N}, \mathrm{P}, \mathrm{K}, \mathrm{Ca}$ and $\mathrm{Mg} \%$. In the vegetative growth, floral parameters as well as anatomical characters elements (N, P, K, $\mathrm{Ca}$ and $\mathrm{Mg} \%)$ in the leaves also significantly decreased. Whereas, $\mathrm{Na} \%$, proline concentration, the activity of $(\mathrm{O}-2$
ABSTRACT: To avoid the hazard effect of salinity on calendula (Calendula officinalis L.), two field experiments were carried out at Sahl El-Husseinieh Research Station, Al-Sharqia Governorate, Egypt during two successive winter seasons of 2017/2018 and 2018/2019 in silty clay soil to evaluate the effects of foliar spraying with yeast at 0 , 4,8 and $12 \mathrm{~g} \mathrm{l}^{-1}$, proline at $0,50,75$ and $100 \mathrm{mg} \mathrm{l}^{-1}$ and the interaction between them. The obtained results showed that foliar application of proline, yeast and their interactions led to improve and increase plant growth, floral, physiological and biochemical characters of calendula plants significantly more than those obtained by control, such as plant height, number of branches plant $^{-1}$, plant fresh and dry weights, number of flowers plant ${ }^{-1}$, flowers fresh and dry weight, relative water of leaves were significantly decreased under salt stress conditions. The physiological and biochemical characters such as photosynthetic pigments content, relative water content (RWC \%) and mineral and $\left.\mathrm{H}_{2} \mathrm{O} 2\right)$ and electrolyte leakage (EL \%) were increased. Moreover, available $\mathrm{N}, \mathrm{P}$ and $\mathrm{K}\left(\mathrm{mg} \mathrm{kg}^{-1}\right)$ in the soil is negatively affected by salt stress. The combined treatments of proline at $100 \mathrm{mg} \mathrm{l}^{-1}+$ yeast at 12 $\mathrm{g} \mathrm{l}^{-1}$ followed by proline at $100 \mathrm{mg}^{-1}+$ yeast at $8 \mathrm{~g} \mathrm{l}^{-1}$ gave the higher values of plant growth, biochemical and elemental content in plant besides improved the anatomical characters, consequently, increased the tolerance of calendula plants to salt stress under field conditions.

Key words: Calendula officinalis L., Salt stress, Proline, Anatomical structure, Enzymes activity. 


\section{INTRODUCTION}

Calendula (Calendula officinalis L.), belongs to Asteraceae (Composite) family, commonly known as pot marigold. It is an annual flowering winter plant in Egypt, it has an attractive colour of flower which are used as a cut flower and also grown for medicinal use (Rigane et al., 2013). Marigold is used as a source of natural pigment in the foods industry and in the cure of pain and skin disorders as well as a bactericide, antiseptic and anti-inflammatory (El-Gamal, 2015).

Salinity stress seriously affects more than a third of the world's cultivated land (Bayat et al., 2012), causes many harmful effects on plants, a sharp decrease in the yield of many plants and biomass, leads to growth reduction as well as metabolic changes similar to those caused by water stress (Abdelaal, 2015a; Abdelaal et al., 2017; El-Banna and Abdelaal, 2018 and Hafez et al., 2020). Furthermore, salt stress causes ion imbalance, osmotic stress, especially with $\mathrm{Ca}, \mathrm{K}$ and the direct poisonous effects of ions on the metabolic operation (Hashish et al., 2015). The high saline levels can cause hyper osmotic and hyper ionic effects on plants, leading to increment reactive oxygen species (ROS) levels and membrane damage (El-Banna and Abdelaal, 2018 and Abdelaal et al., 2020a). The harmful effects of salinity on plants are attributed to oxidative and osmotic stresses (Helaly et al., 2017; Mansour and Ali, 2017 and Abdelaal et al., 2020b). Salty soil has injurious effects on soil chemical and physical characters and causes nutrient shortages. Naher et al. (2011) indicated that salt stress led to increase soil $\mathrm{pH}, \mathrm{EC}$ and commutable Na nutrient, shortages of total nitrogen, potassium and phosphorous were very predominant. Potassium, phosphorus, nitrogen and calcium contents in tissues significantly reduced when soil salinity increased.

Currently, a great attention has been focused on the application of natural and safe components to counteract the deleterious effects of salt stress on plant growth and improve plant growth as well as yield production. Proline is an amino acid, it has a main role in primary metabolism as a component of proteins. It is one of the most widely distributed compatible solutes accumulate during various stress conditions such as salinity, drought or low temperatures (Lehmann et al., 2010). The suggested roles of proline under stress are an antioxidative defense molecule and as a signaling molecule to control mitochondrial functions, influence cell death and release special gene expression which can be necessary for plant recovery under stress (Hayat et al., 2012). In addition to its role in keeping membrane stability, osmoregulation, seed germination and plant growth (Hare et al., 2003). Under salinity stress, Sadak and Mostafa (2015) stated that proline treatment led to decrease oxidative stress and improve the plant growth as well as yield production in sunflower plants. Also, enzymes activity such as catalase (CAT) and peroxidase (POX) were significantly increased in saltstressed Pancratium maritimum plants treated with proline compared with untreated plants (Khedr et al., 2003). Exogenous application of proline alleviates the adverse effect on fresh and dry weights as well as chlorophyll content of salt-stressed Cucumis seedlings (Yan et al., 2011), increases N, P, $\mathrm{K}^{+}$and $\mathrm{Ca}^{+2} \%$, the $\mathrm{K}^{+} / \mathrm{Na}^{+}$ratio, decreases $\mathrm{Na}^{+}, \mathrm{Cl}^{-}$and reduces the harmful effect of salinity on the anatomical structure in Vicia faba (Dawood et al., 2014) and reduces the harmful effect of $\mathrm{NaCl}$ stress on tobacco plants (Hoque et al., 2008).

Yeast is a natural, safe biofertilizer has a pivotal role in improving plant growth. It is considered as a natural source of cytokinins and B-vitamin (Amer, 2004 and Matter and Abou-Sreea, 2016), organic compounds (protein, carbohydrates, nucleic acid, lipids and most nutrient elements) as well as growth substances such as thiamine, riboflavin, pyridoxine, folic acid and vitamin B12 (Nagodowithana, 1991). Application of yeast extract to calendula decreased conspicuously the risk effects of salinity and improved vegetative and growth characters as well as floral characters under saline and 
non-saline conditions of calendula (Nofal et $a l ., 2015)$ and leucaena plants (Nassar et al., 2016). The application of yeast extract led to enhance plant growth, increase potassium content, but, reduce sodium and proline under salt stress conditions in fennel (Mostafa, 2015).

In the recent years, there is a global direction to use safe and natural products in agricultural production to protect human health and environmental balance. Therefore, the aim of this study aimed to use osmoprotectant (proline) and yeast extract (natural material) for improving growth and flowering of Calendula officinalis as well as physiological, biochemical and anatomical characters under salt stress conditions.

\section{MATERIALS AND METHODS}

Two field experiments were carried out at Sahl El-Husseinieh Research Station, Agriculture Research Center, Sharqia Governorate during two successive seasons of 2017/2018 and 2018/2019, and the laboratory investigations were carried out at (EPCRS) Excellence Center and Plant Pathology and Biotechnology Lab., Department of Agricultural Botany, Faculty of Agriculture, Kafrelsheikh University, Egypt, the aim of this study was to reduce the harmful effect of soil salinity on the growth and physiological parameters as well as the flowering of Calendula officinalis by foliar spraying with proline and yeast extract.

\section{Plant materials and experimental design:}

The experiment was conducted in a split plot in randomized complete block design, the main plot which was yeast extract at four levels $\left(0,4,8,12 \mathrm{~g} \mathrm{l}^{-1}\right)$ and the subplot which was proline (L-Proline 99\%) at four levels $\left(0,50,75,100 \mathrm{mg} \mathrm{l}^{-1}\right)$. All treatments were sprayed on the foliage of calendula plants till falling of the first drop for three times (every two weeks). The experimental treatments were 16 treatments with three replicates. The experimental area (plot) was $10.8 \mathrm{~m}^{2}(3 \mathrm{~m} \times$ $3.6 \mathrm{~m}$ ) containing 3 rows. Every row contained nine plants.
Seeds of calendula were obtained from Elzoharia garden, Hort. Res. Inst., ARC, Ministry of Agriculture, Egypt. Seeds were sown on 28 September during two seasons in the hills at $40 \mathrm{~cm}$ distance between the hills. Thinning for one plant hill-1 was done at 45 days after sowing, the irrigation was executed out whenever plants needed and weeds were removed by hand. The experiment was fertilized by the recommended rates from the Egyptian Ministry of Agriculture. The rate of $\mathrm{N}$ was $300 \mathrm{~kg} \mathrm{fed}^{-1}$ (771 $\mathrm{g} \mathrm{plot}^{-1}$ ammonium sulfate) at three doses, the period between them is one month, the first one after one month of cultivation. The rate of $\mathrm{P}$ was $200 \mathrm{~kg} \mathrm{fed}^{-1}$ (514 $\mathrm{g} \mathrm{plot}^{-1}$ calcium superphosphate) added before cultivation. $\mathrm{K}$ was $100 \mathrm{~kg}^{\mathrm{fed}} \mathrm{d}^{-1}(257 \mathrm{~g}$ plot $^{-1}$ potassium sulfate) at two doses added with the first and second doses of nitrogen.

\section{Soil chemical and mechanical analysis:}

A composite soil sample was taken from the surface soil $(0-30 \mathrm{~cm})$ of the experimental sites before any practices and was air-dried, sieved by $2 \mathrm{~mm}$ sieve and analyzed. Physico-chemical properties were conducted as the following. Distribution of particle size by utilizing the pipette method according to Dewis and Fertias (1970), electrical conductivity and the soil $\mathrm{pH}$ of saturated soil paste extract according to Jackson (1967) and Richards (1954). Data of soil analysis were recorded in Table (1).

\section{Morphological growth characters:}

At maturity (after 105 days from planting) nine plants were randomly taken from each plot for determining the following characters. Plant height $(\mathrm{cm})$, number of branches plant ${ }^{-1}$, fresh and dry weights of plant (g plant $\left.{ }^{-1}\right)$.

\section{Floral characters:}

Number of flowers, flower diameter (cm), flowers fresh and dry weights $\left(\mathrm{g} \mathrm{plant}^{-1}\right)$ as well as vase life of flower (days). 
Ghada M.R. El-Shawa et al.

Table 1. Chemical and mechanical analysis of experimental soil.

\begin{tabular}{|c|c|c|c|c|c|c|c|c|c|c|c|}
\hline \multirow[b]{2}{*}{ Seasons } & \multicolumn{5}{|c|}{ Mechanical analysis (\%) } & & \multirow[b]{2}{*}{$\begin{array}{c}\text { Organic } \\
\text { matter }\end{array}$} & \multicolumn{4}{|c|}{ Chemical analysis } \\
\hline & $\begin{array}{c}\text { Sand } \\
(\%)\end{array}$ & & $\begin{array}{l}\text { Silt } \\
\% \text { \%) }\end{array}$ & $\begin{array}{l}\text { Clay } \\
(\%)\end{array}$ & $\begin{array}{c}\text { Textur } \\
\text { grade }\end{array}$ & & & $\begin{array}{c}\mathrm{CaCO}_{3} \\
(\%)\end{array}$ & $\begin{array}{c}\text { pH } \\
(1.2 .5)\end{array}$ & $d S$ & $\begin{array}{l}\text { E.C. } \\
\mathrm{n}^{-1}(1.5)\end{array}$ \\
\hline 201 & 19.5 & & 8.5 & 52 & Clay & & 1.14 & 3.2 & 8.15 & & 3.64 \\
\hline \multirow{3}{*}{ 2018/2019 } & 19 & & 28 & 53 & Clay & & 1.09 & 2.1 & 8.25 & & 4.33 \\
\hline & \multicolumn{3}{|c|}{ Available (mg kg-1) } & \multicolumn{4}{|c|}{ Cations (meq $\mathrm{l}^{-1}$ ) } & \multicolumn{4}{|c|}{ Anions (meq $\left.\mathrm{l}^{-1}\right)$} \\
\hline & $\mathbf{N}$ & $\mathbf{P}$ & $\mathbf{K}$ & $\mathrm{Ca}^{++}$ & $\mathbf{M g}^{++}$ & $\mathbf{N a}^{+}$ & $\mathbf{K}^{+}$ & $\mathrm{CO}_{3}^{--}$ & $\mathrm{HCO}_{3}^{-}$ & $\mathrm{Cl}^{-}$ & $\mathrm{SO}_{4}^{--}$ \\
\hline & 56 & & 78 & 6.70 & 4.98 & & 0.3 & - & 1.50 & $19.6^{\circ}$ & 15.00 \\
\hline 2018/2019 & 52 & 8.0 & 215.48 & 9.05 & 6.25 & 27.30 & 0.41 & - & 2.43 & 22.23 & 18.35 \\
\hline
\end{tabular}

\section{Physiological and biochemical studies:}

Determination of chlorophylls and carotenoids. Total chlorophylls in the leaves and $\beta$-carotene contents in flowers were determined according to Sumanta et al. (2014).

Determination of proline, reactive oxygen species (superoxide and hydrogen peroxide) and enzymes activity. Proline was determined according to Bates et al. (1973). Superoxide and hydrogen peroxide were determined according to Adam et al. (1989) and Hückelhoven et al. (1999). Activities of catalase (CAT) enzyme were assayed according to Aebi (1983). POX was assayed according to (Hammerschmidt et al.,1982). PPO activity was assayed according to Malik and Singh (1980).

\section{Relative water content and electrolyte leakage:}

Relative water content (RWC \%) was measured according to Sanchez et al. (2004) using the following equation RWC $=($ fresh weight - dry weight) / (turgid weight - dry weight $) \times 100$. Electrolyte leakage $($ EL \%) was estimated according to Dionisio-Sese and Tobita (1998) by calculating initial electrical conductivity/final electrical conductivity $\mathrm{x} 100 . \mathrm{EL} \%=\mathrm{EC} 1 / \mathrm{EC} 2 \times 100$.

\section{Mineral contents:}

Determination of nitrogen, phosphorus, potassium, calcium, magnesium and sodium contents in plants. The samples were dried at $70{ }^{\circ} \mathrm{C}$ then crushed and digested using $\mathrm{H}_{2} \mathrm{SO}_{4}$ and $\mathrm{HClO}_{4}$ acids according to Cottenie et al. (1982). Nitrogen (N \%) was determined as described by Official Analytical (A.O.A.C., 1990). Phosphorus
(P \%) was determined as described by Olsen and Sommers (1982). Potassium (K \%) and sodium $\left(\mathrm{Na}^{+} \%\right)$ were determined as described by Jackson (1967). Calcium $(\mathrm{Ca} \%)$ and magnesium (Mg\%) were determined using inductively coupled spectrometry plasma (ICP) Model UltimateJobin Yvon.

\section{Anatomical characters:}

The samples (5 mm length) were taken at the age of 70 days from the leaves during the second season (2018/2019). Was determined according to (Nassar and ElSahhar, 1998). Slides were investigated and photomicrographed.

\section{Statistical analysis:}

Statistical analysis was done by using the analysis of variance technique by means of the Co-Stat Computer Software version 6.303. The mean was compared by Duncan's Multiple Range Test (Duncan, 1955) (DMRT, $\mathrm{P} \leq 0$. 05) (Gomez and Gomez, 1984).

\section{RESULTS}

\section{Morphological growth characters:}

Data presented in Table (2) showed that proline, yeast extract and their combination caused a significant increase in plant height of Calendula officinalis, number of branches, fresh and dry weights of plants compared with control plants. Foliar application of $100 \mathrm{mg} \mathrm{l}^{-1}$ proline resulted in significant increases in the different growth parameters, compared with other proline concentrations and control (81.06 and 79.97 $\mathrm{cm}$ for plant height, 17.14 and 16.22 branches plant ${ }^{-1}$ for the number of branches, 
Table 2. Effect of proline, yeast and their interaction on plant height $(\mathrm{cm})$, number of branches/plant, plant fresh and dry weights (g) of calendula plants in the two seasons.

\begin{tabular}{cccccccccccc}
\hline $\begin{array}{c}\text { Yeast } \\
\left(\mathbf{g ~ l}^{-1}\right)\end{array}$ & Control & $\mathbf{5 0}$ & $\mathbf{7 5}$ & $\mathbf{1 0 0}$ & Mean & Control & $\mathbf{5 0}$ & $\mathbf{7 5}$ & $\mathbf{1 0 0}$ & Mean \\
& & & & $\mathbf{1}^{\text {st }}$ season
\end{tabular}

\section{Plant fresh weight (g)}

Control 225.67h 539.40fg 575.40d-f 594.23c-f 483.68d 229.89g 525.26e 511.10ef 696.01ab 490.56b

$4 \quad 486.00 \mathrm{~g} \quad 544.70 \mathrm{f} \quad 578.03 \mathrm{~d}$-f608.67c-e 554.35c $450.31 \mathrm{f}$ 536.10de 552.77de 603.37cd 535.64b

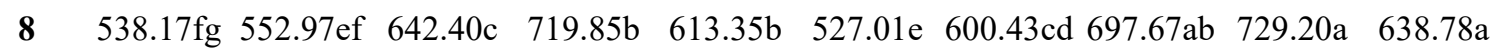

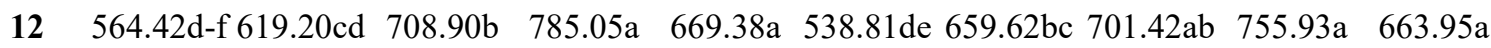

$\begin{array}{llllllllll}\text { Mean } & 453.56 \mathrm{~d} & 564.06 \mathrm{c} & 626.18 \mathrm{~b} & 676.95 \mathrm{a} & & 436.51 \mathrm{~d} & 580.35 \mathrm{c} & 615.74 \mathrm{~b} & 696.13 \mathrm{a}\end{array}$

\begin{tabular}{ccccccccccc}
\hline & \multicolumn{10}{c}{ Plant dry weight (g) } \\
Control & $42.43 \mathrm{i}$ & $93.90 \mathrm{~g}$ & $102.40 \mathrm{ef}$ & $106.27 \mathrm{e}$ & $86.25 \mathrm{~d}$ & $43.22 \mathrm{~g}$ & $97.75 \mathrm{de}$ & $90.58 \mathrm{e}$ & $123.64 \mathrm{~b}$ & $88.80 \mathrm{c}$ \\
$\mathbf{4}$ & $81.47 \mathrm{~h}$ & $96.50 \mathrm{fg}$ & $104.73 \mathrm{e}$ & $109.00 \mathrm{e}$ & $97.93 \mathrm{c}$ & $77.14 \mathrm{f}$ & $98.00 \mathrm{de}$ & $101.17 \mathrm{~d}$ & $110.22 \mathrm{c}$ & $96.63 \mathrm{~b}$ \\
$\mathbf{8}$ & $93.60 \mathrm{~g}$ & $107.55 \mathrm{e}$ & $128.35 \mathrm{c}$ & $137.77 \mathrm{~b}$ & $116.82 \mathrm{~b}$ & $91.78 \mathrm{e}$ & $115.58 \mathrm{c}$ & $138.56 \mathrm{a}$ & $139.78 \mathrm{a}$ & $121.42 \mathrm{a}$ \\
$\mathbf{1 2}$ & $101.93 \mathrm{ef}$ & $118.40 \mathrm{~d}$ & $138.28 \mathrm{~b}$ & $147.80 \mathrm{a}$ & $126.60 \mathrm{a}$ & $97.04 \mathrm{de}$ & $125.31 \mathrm{~b}$ & $136.07 \mathrm{a}$ & $139.86 \mathrm{a}$ & $124.57 \mathrm{a}$ \\
Mean & $79.86 \mathrm{~d}$ & $104.09 \mathrm{c}$ & $118.44 \mathrm{~b}$ & $125.21 \mathrm{a}$ & & $77.30 \mathrm{~d}$ & $109.16 \mathrm{c}$ & $116.59 \mathrm{~b}$ & $128.37 \mathrm{a}$ & \\
\hline
\end{tabular}

Mean values followed by the same letters are not significantly different at the $P<0.05$ according to Duncan's multiple range test.

676.95 and $696.13 \mathrm{~g} \mathrm{plant}^{-1}$ for plant fresh weight, 125.21 and $128.37 \mathrm{~g} \mathrm{plant}^{-1}$ for plant dry weight during the two seasons, respectively). The obtained results in Table (2) revealed that application of yeast at 12 $\mathrm{g}^{-1}$ recorded the highest mean values in plant height, number of branches, plant fresh and dry weights in both seasons respectively.

Concerning the effect of the interactions between proline and yeast extract on morphological growth characters, data presented in the same Table showed that there were significant differences between treatments. The plants sprayed with proline at $100 \mathrm{mg}^{-1}$ in combination with yeast extract at $12 \mathrm{~g} \mathrm{l}^{-1}$ resulted in a maximum plant height $(86.00$ and $85.50 \mathrm{~cm})$, number of branches plant ${ }^{-1}$ (20.89 and 20.67), plant fresh weight (785.05 and $755.93 \mathrm{~g} \mathrm{plant}^{-1}$ ) and plant dry weight (147.80 and $139.86 \mathrm{~g}$ plant $^{-1}$ ) in the two seasons, respectively.

\section{Floral characters:}

Application of the different proline treatments significantly promoted the production of flowers, flowers fresh and dry weights, flower diameter and vase life of flowers in both seasons as shown in Table (3). Proline treatment at $100 \mathrm{mg} \mathrm{l}^{-1}$ had the most promising effect in improving flowering quality. Also, this treatment gave a greatest number of flowers (163.64 and 
Table 3. Effect of proline, yeast and their interaction on number of flowers, flower fresh and dry weight (g/flower), flower diameter $(\mathrm{cm})$ and vase life (day) of calendula plants in the two seasons.

\begin{tabular}{|c|c|c|c|c|c|c|c|c|c|c|}
\hline \multirow[b]{2}{*}{$\begin{array}{l}\text { Yeast } \\
\left(\mathrm{g} \mathrm{l}^{-1}\right)\end{array}$} & \multicolumn{5}{|c|}{ Proline $\left(\mathrm{mg} \mathrm{l}^{-1}\right)$} & \multicolumn{5}{|c|}{ Proline $\left(\mathrm{mg} \mathrm{l}^{-1}\right)$} \\
\hline & \multicolumn{4}{|c|}{$1^{\text {st }}$ season } & Mean & \multicolumn{4}{|c|}{$2^{\text {nd }}$ season } & Mean \\
\hline & \multicolumn{10}{|c|}{ No. of flowers } \\
\hline Control & $54.67 \mathrm{~h}$ & $115.00 \mathrm{f}$ & $119.67 f$ & $140.00 \mathrm{de}$ & $107.33 d$ & $52.67 \mathrm{i}$ & $112.67 \mathrm{fg}$ & $118.00 \mathrm{e}-\mathrm{g}$ & $134.00 \mathrm{de}$ & $104.33 d$ \\
\hline 4 & $91.00 \mathrm{~g}$ & $117.33 \mathrm{f}$ & $132.00 \mathrm{e}$ & $148.23 \mathrm{~d}$ & $122.14 \mathrm{c}$ & $89.00 \mathrm{~h}$ & $116.67 \mathrm{e}-\mathrm{g}$ & $131.33 \mathrm{~d}-\mathrm{f}$ & $145.67 \mathrm{~cd}$ & $120.67 \mathrm{c}$ \\
\hline 8 & $112.67 f$ & $142.33 \mathrm{~d}$ & $149.67 d$ & $175.00 \mathrm{~b}$ & $144.92 b$ & $107.67 \mathrm{~g}$ & $139.33 d$ & $150.67 \mathrm{~cd}$ & $170.33 b$ & $142.00 \mathrm{~b}$ \\
\hline 12 & $119.33 f$ & $161.33 c$ & $165.33 \mathrm{c}$ & $191.33 \mathrm{a}$ & $159.33 \mathrm{a}$ & $117.33 \mathrm{e}-\mathrm{g}$ & $158.67 \mathrm{bc}$ & $163.33 \mathrm{bc}$ & $188.33 \mathrm{a}$ & $156.92 \mathrm{a}$ \\
\hline \multirow[t]{2}{*}{ Mean } & $94.42 d$ & $134.00 \mathrm{c}$ & $141.67 \mathrm{~b}$ & $163.64 \mathrm{a}$ & & $91.67 d$ & $131.83 \mathrm{c}$ & $140.83 b$ & $159.58 \mathrm{a}$ & \\
\hline & \multicolumn{10}{|c|}{ Flowers fresh weight (g) } \\
\hline Control & $117.17 \mathrm{e}$ & $394.00 \mathrm{~cd}$ & $407.30 \mathrm{c}$ & $434.10 b c$ & $338.14 b$ & $112.67 \mathrm{~g}$ & $379.81 \mathrm{de}$ & $398.94 c-e$ & $413.38 b-d$ & $326.20 \mathrm{c}$ \\
\hline 4 & $345.47 \mathrm{~d}$ & $399.87 \mathrm{c}$ & $409.80 \mathrm{c}$ & $441.97 \mathrm{a}-\mathrm{c}$ & $399.28 \mathrm{a}$ & $325.07 f$ & $384.63 \mathrm{c}-\mathrm{e}$ & $400.50 \mathrm{c}-\mathrm{e}$ & $439.73 b$ & $387.48 b$ \\
\hline 8 & $387.67 \mathrm{~cd}$ & $400.90 \mathrm{c}$ & $414.47 \mathrm{bc}$ & $464.90 \mathrm{ab}$ & $416.98 \mathrm{a}$ & $372.57 \mathrm{e}$ & $393.40 \mathrm{c}-\mathrm{e}$ & $409.77 b-d$ & $470.73 a$ & $411.62 \mathrm{a}$ \\
\hline 12 & $389.07 \mathrm{~cd}$ & $401.23 c$ & $422.47 \mathrm{bc}$ & $491.60 \mathrm{a}$ & $426.10 \mathrm{a}$ & $380.83 \mathrm{de}$ & $396.03 c-e$ & $417.87 \mathrm{bc}$ & $478.73 a$ & $418.37 \mathrm{a}$ \\
\hline \multirow[t]{2}{*}{ Mean } & $309.84 \mathrm{c}$ & $399.00 \mathrm{~b}$ & $413.51 b$ & $458.14 \mathrm{a}$ & & $297.78 d$ & $388.47 \mathrm{c}$ & $406.78 b$ & $450.65 a$ & \\
\hline & \multicolumn{10}{|c|}{ Flowers dry weight (g) } \\
\hline Control & $33.49 \mathrm{f}$ & 98.34de & $106.79 \mathrm{~cd}$ & $117.77 b-d$ & $89.10 \mathrm{c}$ & $32.97 \mathrm{j}$ & $94.31 \mathrm{~h}$ & $104.12 \mathrm{~d}-\mathrm{h}$ & $111.65 \mathrm{c}-\mathrm{e}$ & $85.76 \mathrm{~d}$ \\
\hline 4 & $85.82 \mathrm{e}$ & $101.73 \mathrm{de}$ & $106.92 \mathrm{~cd}$ & 121.76a-c & $104.06 \mathrm{~b}$ & $82.62 \mathrm{i}$ & $97.31 \mathrm{gh}$ & $104.17 \mathrm{~d}-\mathrm{h}$ & $120.75 b c$ & $101.21 \mathrm{c}$ \\
\hline 8 & $103.82 \mathrm{c}-\mathrm{e}$ & $106.44 \mathrm{~cd}$ & $111.07 b-d$ & $127.01 \mathrm{ab}$ & $112.09 \mathrm{ab}$ & $100.74 f-h$ & $104.64 d-g$ & $108.92 \mathrm{df}$ & $127.57 \mathrm{ab}$ & $110.47 b$ \\
\hline 12 & $104.74 \mathrm{~cd}$ & 109.10b-d & $115.25 b-d$ & $136.42 \mathrm{a}$ & $116.37 \mathrm{a}$ & $101.68 \mathrm{e}-\mathrm{h}$ & $106.94 d-g$ & $113.12 \mathrm{~cd}$ & $132.13 \mathrm{a}$ & $113.47 \mathrm{a}$ \\
\hline \multirow[t]{2}{*}{ Mean } & $81.97 \mathrm{c}$ & $103.90 \mathrm{~b}$ & $110.01 b$ & $125.74 \mathrm{a}$ & & $79.50 \mathrm{~d}$ & $100.8 \mathrm{c}$ & $107.58 b$ & $123.03 \mathrm{a}$ & \\
\hline & \multicolumn{10}{|c|}{ Flower diameter $(\mathrm{cm})$} \\
\hline Control & $4.84 \mathrm{i}$ & $6.77 \mathrm{gh}$ & $6.87 \mathrm{e}-\mathrm{h}$ & $7.03 \mathrm{c}-\mathrm{h}$ & $6.38 \mathrm{c}$ & $5.17 \mathrm{j}$ & $6.63 \mathrm{~g}-\mathrm{i}$ & $6.80 \mathrm{e}-\mathrm{h}$ & $7.07 \mathrm{c}-\mathrm{f}$ & $6.42 \mathrm{~d}$ \\
\hline 4 & $6.53 \mathrm{~h}$ & $6.80 \mathrm{f}-\mathrm{h}$ & $6.97 \mathrm{~d}-\mathrm{h}$ & $7.30 \mathrm{~b}-\mathrm{f}$ & $6.90 \mathrm{~b}$ & $6.40 \mathrm{i}$ & $6.73 \mathrm{e}-\mathrm{i}$ & $6.93 \mathrm{~d}-\mathrm{g}$ & $7.27 b-d$ & $6.83 \mathrm{c}$ \\
\hline 8 & $6.63 \mathrm{~h}$ & $7.17 \mathrm{~b}-\mathrm{g}$ & $7.43 b-d$ & $7.63 \mathrm{ab}$ & $7.22 \mathrm{a}$ & $6.50 \mathrm{hi}$ & 7.10c-e & $7.33 b c$ & $7.53 \mathrm{ab}$ & $7.11 b$ \\
\hline 12 & $6.80 \mathrm{f}-\mathrm{h}$ & $7.37 \mathrm{~b}-\mathrm{e}$ & $7.50 \mathrm{a}-\mathrm{c}$ & $7.97 \mathrm{a}$ & $7.41 \mathrm{a}$ & $6.70 \mathrm{f}-\mathrm{i}$ & $7.30 \mathrm{~b}-\mathrm{d}$ & $7.43 \mathrm{bc}$ & $7.83 \mathrm{a}$ & $7.31 \mathrm{a}$ \\
\hline \multirow[t]{2}{*}{ Mean } & $6.20 c$ & $7.03 b$ & $7.19 b$ & $7.48 \mathrm{a}$ & & $6.19 \mathrm{~d}$ & $6.94 \mathrm{c}$ & $7.13 b$ & $7.43 \mathrm{a}$ & \\
\hline & \multicolumn{10}{|c|}{ Vase life (days) } \\
\hline Control & $6.33 \mathrm{~g}$ & $6.83 \mathrm{~g}$ & $8.33 \mathrm{f}$ & $9.00 \mathrm{ef}$ & $7.63 \mathrm{c}$ & $6.00 \mathrm{e}$ & $6.67 \mathrm{e}$ & $8.11 \mathrm{~d}$ & $8.67 \mathrm{~cd}$ & $7.36 \mathrm{c}$ \\
\hline 4 & $6.67 \mathrm{~g}$ & $7.00 \mathrm{~g}$ & $8.50 \mathrm{f}$ & $10.00 \mathrm{~cd}$ & $8.04 \mathrm{c}$ & $6.33 \mathrm{e}$ & $6.89 \mathrm{e}$ & $8.33 \mathrm{~d}$ & $9.67 \mathrm{bc}$ & $7.81 \mathrm{c}$ \\
\hline 8 & $6.67 \mathrm{~g}$ & $9.33 \mathrm{de}$ & $10.67 b c$ & $11.33 \mathrm{ab}$ & $9.50 \mathrm{~b}$ & $6.56 \mathrm{e}$ & $9.11 \mathrm{~cd}$ & $10.33 \mathrm{ab}$ & $11.00 \mathrm{a}$ & $9.25 \mathrm{~b}$ \\
\hline 12 & $7.00 \mathrm{~g}$ & $10.83 b$ & $10.67 \mathrm{bc}$ & $11.67 \mathrm{a}$ & $10.04 \mathrm{a}$ & $6.89 \mathrm{e}$ & $10.67 \mathrm{ab}$ & $10.56 \mathrm{ab}$ & $11.33 \mathrm{a}$ & $9.86 \mathrm{a}$ \\
\hline Mean & $6.67 \mathrm{~d}$ & $8.50 \mathrm{c}$ & $9.54 b$ & $10.50 \mathrm{a}$ & & $6.45 \mathrm{~d}$ & $8.33 c$ & $9.33 b$ & $10.17 \mathrm{a}$ & \\
\hline
\end{tabular}

Mean values followed by the same letters are not significantly different at the $\mathbf{P}<0.05$ according to Duncan's multiple range test.

159.58 flower plant $^{-1}$ ), maximum fresh weight of flowers (458.14 and $450.65 \mathrm{~g}$ plant $\left.^{-1}\right)$, flowers dry weight (125.74 and $\left.123.03 \mathrm{~g} \mathrm{plant}^{-1}\right)$, flower diameter (7.48 and $7.43 \mathrm{~cm})$ and flower vase life $(10.50$ and 10.17 days) in the two seasons, respectively. The presented data in Table (3) revealed that all the mean values of floral parameters significantly increased with the different concentrations of yeast extract compared with the untreated plants. Yeast extract at 12 $\mathrm{g}^{-1}$ represented the highest values among all levels which gave the highest flower number (159.33 and 156.92 flower plant ${ }^{-1}$ ), fresh weight of flower (426.10 and 418.37 g plant $\left.^{-1}\right)$, dry weight of flowers (116.37 and $\left.113.47 \mathrm{~g} \mathrm{plant}^{-1}\right)$, flower diameter (7.41 and $7.31 \mathrm{~cm})$ and flower vase life $(10.04$ and 9.86 days) respectively, in the two seasons. Regarding the effect of interactions between 
proline and yeast on flowering characters, there was a significant difference between treatments in both seasons (Table, 3). The best treatment was proline at $100 \mathrm{mg} \mathrm{l}^{-1}+$ yeast extract at $12 \mathrm{~g} \mathrm{l}^{-1}$ which gave the highest values in all floral parameters in the two seasons.

\section{Physiological and biochemical studies:}

\section{Photosynthetic pigments content:}

Application of proline at all concentrations caused significant increases in carotenoids and total chlorophyll in both seasons as presented in Table (4). The highest values of carotenoids (26.70 and $27.25 \mathrm{mg} 100 \mathrm{~g}^{-1} \mathrm{fw}$ ) and total chlorophylls (0.917 and $0.895 \mathrm{mg} \mathrm{g}^{-1} \mathrm{fw}$ ) were recorded for plants treated with proline at $100 \mathrm{mg} \mathrm{l}^{-1}$ in the two seasons, respectively. As shown in the same table, yeast extract treatments significantly affected carotene and chlorophyll content in the two seasons. Yeast extract treatment at $12 \mathrm{~g}^{-1}$ gave the highest values of carotene (26.55 and $27.30 \mathrm{mg} 100$ $\left.\mathrm{g}^{-1} \mathrm{fw}\right)$ and chlorophyll content (0.909 and $\left.0.884 \mathrm{mg} \mathrm{g}^{-1} \mathrm{fw}\right)$ in the two seasons respectively. It is quite clear from the data presented in the same Table that the interactions between the two factors significantly affected carotene and chlorophyll content. The plants treated with $100 \mathrm{mg} \mathrm{l}^{-1}$ proline $+12 \mathrm{~g}^{-1}$ yeast resulted in a maximum carotene $(27.70$ and $28.70 \mathrm{mg}$ $\left.100 \mathrm{~g}^{-1} \mathrm{fw}\right)$ and total chlorophyll (0.997 and $0.985 \mathrm{mg} \mathrm{g}^{-1} \mathrm{fw}$ ) in the two seasons, respectively.

\section{Proline content:}

Results in Table (4) showed that proline content was decreased in the plants treated with yeast in saline soil. Contrariwise, plants gave the highest response to proline accumulation in the leaves when treated with proline at all concentrations and control plants. Data showed also that plants sprayed with proline at $100 \mathrm{mg} \mathrm{l}^{-1}$ gave the highest

Table 4. Effect of proline, yeast and their interaction on carotene (mg $100 \mathrm{~g}^{-1} \mathrm{fw}$, total chlorophyll ( $\left.\mathrm{mg} \mathrm{g}^{-1} \mathrm{fw}\right)$ and proline $\left(\mu \mathrm{g} \mathrm{g^{-1 }} \mathrm{fw}\right)$ in calendula plants in the two seasons.

\begin{tabular}{|c|c|c|c|c|c|c|c|c|c|c|}
\hline \multirow[b]{2}{*}{$\begin{array}{l}\text { Yeast } \\
\left(\mathrm{g} \mathrm{l}^{-1}\right)\end{array}$} & \multicolumn{5}{|c|}{ Proline $\left(\mathrm{mg} \mathrm{l}^{-1}\right)$} & \multicolumn{5}{|c|}{ Proline $\left(\mathrm{mg} \mathrm{l}^{-1}\right)$} \\
\hline & Control & \multicolumn{3}{|c|}{$1^{\text {st }}$ season } & Mean & Control & 50 & $\begin{array}{c}75 \\
2^{\text {nd }} \text { season }\end{array}$ & 100 & Mean \\
\hline & \multicolumn{10}{|c|}{ Carotene $\left(\mathrm{mg} \mathrm{g}^{-1}\right.$ fw) } \\
\hline Control & $24.20 \mathrm{k}$ & $25.10 \mathrm{i}$ & $25.60 \mathrm{~g}$ & $26.00 \mathrm{f}$ & $25.23 \mathrm{~d}$ & $25.30 \mathrm{~h}$ & $25.90 \mathrm{~g}$ & $26.30 \mathrm{ef}$ & 26.40de & $25.98 \mathrm{~d}$ \\
\hline 4 & $24.90 \mathrm{j}$ & $25.40 \mathrm{~h}$ & $25.60 \mathrm{~g}$ & $26.20 \mathrm{e}$ & $25.53 \mathrm{c}$ & $25.40 \mathrm{~h}$ & $26.10 \mathrm{fg}$ & $26.40 \mathrm{de}$ & $26.60 \mathrm{~d}$ & $26.13 \mathrm{c}$ \\
\hline 8 & $25.00 \mathrm{ij}$ & $26.20 \mathrm{e}$ & $26.50 \mathrm{~d}$ & $26.90 \mathrm{~b}$ & $26.15 b$ & $25.90 \mathrm{~g}$ & $26.60 \mathrm{~d}$ & $27.20 \mathrm{~b}$ & $27.30 \mathrm{~b}$ & $26.75 b$ \\
\hline 12 & $25.50 \mathrm{gh}$ & $26.30 \mathrm{e}$ & $26.70 \mathrm{c}$ & $27.70 \mathrm{a}$ & $26.55 \mathrm{a}$ & $26.30 \mathrm{ef}$ & $26.90 \mathrm{c}$ & $27.30 \mathrm{~b}$ & $28.70 \mathrm{a}$ & $27.30 \mathrm{a}$ \\
\hline \multirow[t]{2}{*}{ Mean } & $24.90 \mathrm{~d}$ & $25.75 \mathrm{c}$ & $26.10 \mathrm{~b}$ & $26.70 \mathrm{a}$ & & $25.73 \mathrm{~d}$ & $26.38 \mathrm{c}$ & $26.80 \mathrm{~b}$ & $27.25 \mathrm{a}$ & \\
\hline & \multicolumn{10}{|c|}{ Total chlorophyll $\left(\mathrm{mg} \mathrm{g}^{-1} \mathbf{f w}\right)$} \\
\hline Control & $0.537 \mathrm{o}$ & 0.7071 & $0.800 \mathrm{i}$ & $0.827 \mathrm{~h}$ & $0.718 \mathrm{~d}$ & $0.480 \mathrm{~m}$ & $0.639 \mathrm{j}$ & $0.773 \mathrm{~h}$ & $0.785 \mathrm{~g}$ & $0.669 \mathrm{~d}-2-\mathrm{c}$ \\
\hline 4 & $0.606 n$ & $0.737 \mathrm{k}$ & $0.825 \mathrm{~h}$ & $0.868 \mathrm{f}$ & $0.759 \mathrm{c}$ & 0.5701 & $0.641 \mathrm{j}$ & $0.778 \mathrm{~h}$ & $0.836 \mathrm{e}$ & $0.706 \mathrm{c}$ \\
\hline 8 & $0.681 \mathrm{~m}$ & $0.861 \mathrm{~g}$ & $0.927 \mathrm{~d}$ & $0.974 \mathrm{~b}$ & $0.861 \mathrm{~b}$ & $0.581 \mathrm{k}$ & $0.800 \mathrm{f}$ & $0.962 \mathrm{c}$ & $0.974 \mathrm{~b}$ & $0.829 b$ \\
\hline 12 & $0.767 \mathrm{j}$ & $0.915 \mathrm{e}$ & $0.957 \mathrm{c}$ & $0.997 \mathrm{a}$ & $0.909 a$ & $0.657 \mathrm{i}$ & $0.931 \mathrm{~d}$ & $0.963 \mathrm{c}$ & $0.985 \mathrm{a}$ & $0.884 a$ \\
\hline \multirow[t]{2}{*}{ Mean } & $0.648 \mathrm{~d}$ & $0.805 \mathrm{c}$ & $0.877 \mathrm{~b}$ & $0.917 \mathrm{a}$ & & $0.572 \mathrm{~d}$ & $0.753 \mathrm{c}$ & $0.869 \mathrm{~b}$ & $0.895 \mathrm{a}$ & \\
\hline & \multicolumn{10}{|c|}{ Proline ( $\left.\mu \mathrm{g} \mathrm{g}^{-1} \mathrm{fw}\right)$} \\
\hline Control & $7.52 \mathrm{~d}$ & $8.62 \mathrm{c}$ & $9.12 b$ & $9.62 \mathrm{a}$ & $8.72 \mathrm{a}$ & $7.50 \mathrm{~d}$ & $7.96 \mathrm{c}$ & $8.77 \mathrm{~b}$ & $9.51 \mathrm{a}$ & $8.43 \mathrm{a}$ \\
\hline 4 & $6.27 \mathrm{~h}$ & $6.42 \mathrm{~g}$ & $7.22 \mathrm{f}$ & $7.41 \mathrm{e}$ & $6.83 b$ & $6.29 \mathrm{~g}$ & $6.63 \mathrm{f}$ & $7.00 \mathrm{e}$ & $7.31 \mathrm{~d}$ & $6.81 \mathrm{~b}$ \\
\hline 8 & $5.96 \mathrm{j}$ & $5.99 \mathrm{j}$ & $6.02 \mathrm{ij}$ & $6.08 \mathrm{i}$ & $6.01 \mathrm{c}$ & $4.36 \mathrm{j}$ & $5.21 \mathrm{i}$ & $6.01 \mathrm{~h}$ & $6.11 \mathrm{gh}$ & $5.42 \mathrm{c}$ \\
\hline 12 & $4.37 \mathrm{n}$ & $5.01 \mathrm{~m}$ & 5.121 & $5.62 \mathrm{k}$ & $5.03 \mathrm{~d}$ & 3.651 & $3.97 \mathrm{k}$ & $4.08 \mathrm{k}$ & $4.20 \mathrm{jk}$ & $3.98 \mathrm{~d}$ \\
\hline Mean & $6.03 \mathrm{~d}$ & $6.51 \mathrm{c}$ & $6.87 \mathrm{~b}$ & $7.18 \mathrm{a}$ & & $5.45 \mathrm{~d}$ & $5.94 \mathrm{c}$ & $6.46 \mathrm{~b}$ & $6.78 \mathrm{a}$ & \\
\hline
\end{tabular}

Mean values followed by the same letters are not significantly different at the $P<0.05$ according to Duncan's multiple range test. 
values of proline content (7.18 and 6.78 $\left.\mu \mathrm{g} \mathrm{g}^{-1} \mathrm{fw}\right)$ comparing with yeast at $12 \mathrm{~g} \mathrm{l}^{-1}$ which gave the lowest values of proline content (5.03 and $3.98 \mu \mathrm{g} \mathrm{g}^{-1} \mathrm{fw}$ ) in the two seasons respectively. As for the interaction between proline and yeast extract, data in presented Table (4) demonstrated that treated plants with proline at $100 \mathrm{mg} \mathrm{l}^{-1}$ without yeast extract gave the highest values of proline content (9.62 and $9.51 \mu \mathrm{g} \mathrm{g}^{-1} \mathrm{fw}$ ) respectively, in the two seasons comparing with the other treatments in the two seasons.

\section{Enzymes activity, relative water content (RWC \%) and electrolyte leakage (EL \%) in calendula leaves in the second season:}

Regarding the effect of salinity on antioxidant enzymes activity, the presented data in Table (5) indicated that application of proline and yeast led to overcome the harmful effects of salinity as well as increase CAT activity, the best results were recorded with $100 \mathrm{mg} \mathrm{l}^{-1}$ proline $+12 \mathrm{~g} \mathrm{l}^{-1}$ yeast followed by $100 \mathrm{mg} \mathrm{l}^{-1}$ proline $+8 \mathrm{~g} \mathrm{l}^{-1}$ yeast respectively, compared with control plants as presented in Table (5). Furthermore, POX and PPO activity significantly increased with most treatments, the best results of POX were obtained at $100 \mathrm{mg} \mathrm{l}^{-1}$ proline $+12 \mathrm{~g} \mathrm{l}^{-1}$ yeast as well as $75 \mathrm{mg} \mathrm{l}^{-1}$ proline $+12 \mathrm{~g} \mathrm{l}^{-1}$ yeast respectively, compared with control plants and other treatments. Likewise, proline and yeast application significantly increased activity of PPO in the stressed plants compared with control plants and the best treatment was $100 \mathrm{mg} \mathrm{l}^{-1}$ proline +12 $\mathrm{g}^{-1}$ yeast. Under salt stress conditions, the levels of superoxide and hydrogen peroxide (ROS) significantly increased in the saltstressed plants (56.67 and 41.80). Nevertheless, these levels of ROS were decreased under various treatments of proline and yeast, the minimum level of superoxide and hydrogen peroxide (24.77 and 22.07) was recorded with the best treatment $\left(100 \mathrm{mg} \mathrm{l}^{-1}\right.$ proline $+12 \mathrm{~g} \mathrm{l}^{-1}$ yeast). Data presented in Table (5) indicated that salt stress led to a significant decrease in relative water content, however, proline and yeast application (50, 75 and $100 \mathrm{mg} \mathrm{l}^{-1}$ proline as well as 4, 8 and $12 \mathrm{~g} \mathrm{l}^{-1}$ yeast) led to improve plant growth and increase the relative water content. The best results were recorded with $100 \mathrm{mg} \mathrm{l}^{-1}$ proline $+12 \mathrm{~g} \mathrm{l}^{-1}$ yeast followed by $100 \mathrm{mg} \mathrm{l}^{-1}$ proline $+8 \mathrm{~g} \mathrm{l}^{-1}$ yeast respectively, compared with other treatments and control plants. Under salt stress conditions, electrolyte leakage percentage was increased in calendula plants, nevertheless, application of proline and yeast at various concentrations decreased electrolyte leakage in salt-stressed calendula plants, the best treatment was $100 \mathrm{mg} \mathrm{l}^{-1}$ proline $+12 \mathrm{~g} \mathrm{l}^{-1}$ yeast followed by $75 \mathrm{mg} \mathrm{l}^{-1}$ proline $+12 \mathrm{~g} \mathrm{l}^{-1}$ yeast respectively, compared with other treatments (Table, 5).

\section{Mineral elements (\%):}

It was noticeable that there was a gradual increase in plant of $\mathrm{N}, \mathrm{P}, \mathrm{K}, \mathrm{Ca}$ and $\mathrm{Mg} \%$ combined with a gradual decrease in $\mathrm{Na}^{+} \%$ in the leaves during the two seasons as shown in Table (6). Proline and yeast application especially at the highest levels (proline at $100 \mathrm{mg} \mathrm{l}^{-1}$ and yeast extract at 12 $\mathrm{g}^{-1}$ ) alleviated the negative effects of salinity and increased the absorption of the previous elements. The highest values of $\mathrm{N} \%$ were obtained with proline at $100 \mathrm{mg} \mathrm{l}^{-1}$ $(1.80$ and $1.59 \%)$ and with yeast extract at $12 \mathrm{~g} \mathrm{l}^{-1}$ (1.78 and $\left.1.57 \%\right)$ in the two seasons, respectively. Also, the same treatments gave the highest values of $\mathrm{P}, \mathrm{K}, \mathrm{Ca}^{+2}$ and $\mathrm{Mg}^{+2} \%$. On the other hand, foliar applications of proline at $100 \mathrm{mg} \mathrm{l}^{-1}$ or yeast extract at $12 \mathrm{~g}$ $1^{-1}$ led to a decrease in the content of $\mathrm{Na}^{+}$in calendula leaves. With regard to the interaction between proline and yeast extract, it is clear from the results listed in Table (6) that the highest $\mathrm{N}, \mathrm{P}, \mathrm{K}, \mathrm{Ca}^{+2}$ and $\mathrm{Mg}^{+2} \%$ were achieved when calendula plants were sprayed with proline at $100 \mathrm{mg} \mathrm{l}^{-1}$ and yeast extract at $12 \mathrm{~g} \mathrm{l}^{-1}$ during the two seasons. On the contrary, the lowest $\mathrm{Na}^{+} \%(0.88$ and $1.01 \%$ ) was obtained when calendula plants were sprayed with the same treatment. 
Table 5. Effect of proline, yeast and their interaction on antioxidant enzymes activity, superoxide, hydrogen peroxide, electrolyte leakage (EL \%) and relative water content (RWC \%) in calendula plants in the second season.

\begin{tabular}{|c|c|c|c|c|c|}
\hline \multirow{2}{*}{ Yeast $\left(\mathrm{g} \mathrm{l}^{-1}\right)$} & \multicolumn{5}{|c|}{ Proline $\left(\mathrm{mg} \mathrm{l}^{-1}\right)$} \\
\hline & Control & 50 mg & $75 \mathrm{mg}$ & 100 & Mean \\
\hline & \multicolumn{5}{|c|}{ Catalase activity $\left(0.1 \mathrm{~min}^{-1} \mathrm{mg}^{-1}\right.$ protein $)$} \\
\hline Control & $42.42 \mathrm{~h}$ & $56.42 \mathrm{~g}$ & $57.00 \mathrm{~g}$ & $70.42 \mathrm{f}$ & $56.57 \mathrm{~d}$ \\
\hline 4 & $77.83 \mathrm{ef}$ & $96.08 \mathrm{~d}$ & $96.67 \mathrm{~d}$ & $104.92 \mathrm{c}$ & $93.88 \mathrm{c}$ \\
\hline 8 & $79.92 \mathrm{e}$ & $112.67 \mathrm{bc}$ & $106.25 \mathrm{c}$ & $115.08 \mathrm{~b}$ & $103.48 \mathrm{~b}$ \\
\hline 12 & $83.33 \mathrm{e}$ & $119.33 b$ & $112.67 \mathrm{bc}$ & $140.42 \mathrm{a}$ & $113.94 \mathrm{a}$ \\
\hline \multirow[t]{2}{*}{ Mean } & $70.88 \mathrm{c}$ & $96.13 b$ & $93.15 b$ & $107.71 \mathrm{a}$ & \\
\hline & \multicolumn{5}{|c|}{$\begin{array}{c}\text { Peroxidase activity }\left(\mathrm{U} \mathrm{mg}^{-1} \mathrm{protein}\right) \\
\left(\mathrm{U}=1 \mathrm{mM} \text { of } \mathrm{H}_{2} \mathrm{O}_{2} \text { reduction } \mathrm{min}^{-1} \mathrm{mg}^{-1} \text { protein }\right)\end{array}$} \\
\hline Control & $0.170 \mathrm{~h}$ & $0.383 \mathrm{~g}$ & $0.383 \mathrm{~g}$ & $0.450 \mathrm{e}-\mathrm{g}$ & $0.347 \mathrm{c}$ \\
\hline 4 & $0.463 \mathrm{~d}-\mathrm{g}$ & $0.513 c-e$ & $0.557 \mathrm{c}$ & $0.663 b$ & $0.542 \mathrm{~b}$ \\
\hline 8 & $0.407 \mathrm{fg}$ & $0.540 \mathrm{~cd}$ & $0.560 \mathrm{c}$ & $0.660 \mathrm{~b}$ & $0.549 \mathrm{~b}$ \\
\hline 12 & $0.487 \mathrm{c}-\mathrm{f}$ & $0.720 \mathrm{ab}$ & $0.693 \mathrm{ab}$ & $0.767 \mathrm{a}$ & $0.667 \mathrm{a}$ \\
\hline \multirow[t]{2}{*}{ Mean } & $0.382 \mathrm{c}$ & $0.539 \mathrm{~b}$ & $0.548 \mathrm{~b}$ & $0.635 \mathrm{a}$ & \\
\hline & \multicolumn{5}{|c|}{ Polyphenol oxidase activity (amount of quinon $\mathrm{g}^{-1} \mathrm{FW} \mathrm{min}^{-1}$ ) } \\
\hline Control & $0.0025 \mathrm{j}$ & $0.0037 \mathrm{ij}$ & $0.0037 \mathrm{ij}$ & $0.0066 \mathrm{gh}$ & $0.0041 d$ \\
\hline 4 & $0.0053 \mathrm{hi}$ & $0.0070 \mathrm{f}-\mathrm{h}$ & $0.0077 \mathrm{e}-\mathrm{g}$ & $0.0080 \mathrm{~d}-\mathrm{g}$ & $0.0070 \mathrm{c}$ \\
\hline 8 & $0.0052 \mathrm{hi}$ & $0.0087 \mathrm{c}-\mathrm{f}$ & $0.0092 \mathrm{c}-\mathrm{e}$ & $0.0135 b$ & $0.0092 b$ \\
\hline 12 & $0.0063 \mathrm{gh}$ & $0.0096 \mathrm{~cd}$ & $0.0103 \mathrm{c}$ & $0.0165 \mathrm{a}$ & $0.0107 \mathrm{a}$ \\
\hline \multirow[t]{2}{*}{ Mean } & $0.0049 \mathrm{c}$ & $0.0072 b$ & $0.0077 \mathrm{~b}$ & $0.0111 \mathrm{a}$ & \\
\hline & \multicolumn{5}{|c|}{ Superoxide (Arbitrary Units) } \\
\hline Control & $56.67 \mathrm{a}$ & $48.33 b$ & $44.53 \mathrm{c}$ & $38.93 \mathrm{de}$ & $47.12 \mathrm{a}$ \\
\hline 4 & $45.33 b c$ & $35.00 \mathrm{f}-\mathrm{h}$ & $33.83 \mathrm{gh}$ & $33.03 \mathrm{gh}$ & $38.33 \mathrm{~b}$ \\
\hline 8 & $40.50 \mathrm{~d}$ & $39.00 \mathrm{de}$ & $37.73 \mathrm{~d}-\mathrm{f}$ & $36.07 \mathrm{e}-\mathrm{g}$ & $36.80 \mathrm{~b}$ \\
\hline 12 & $39.17 \mathrm{de}$ & $32.70 \mathrm{gh}$ & $31.13 \mathrm{~h}$ & $24.77 \mathrm{i}$ & $31.94 \mathrm{c}$ \\
\hline \multirow[t]{2}{*}{ Mean } & $45.42 \mathrm{a}$ & $38.76 \mathrm{~b}$ & $36.81 \mathrm{c}$ & $33.20 \mathrm{~d}$ & \\
\hline & \multicolumn{5}{|c|}{ Hydrogen peroxide (Arbitrary Units) } \\
\hline Control & $41.80 \mathrm{a}$ & $37.33 b c$ & $35.37 \mathrm{~b}-\mathrm{e}$ & $33.00 \mathrm{de}$ & $36.88 \mathrm{a}$ \\
\hline 4 & $38.77 \mathrm{ab}$ & $31.77 \mathrm{e}-\mathrm{g}$ & $32.60 \mathrm{~d}-\mathrm{f}$ & $28.30 \mathrm{gh}$ & $32.86 \mathrm{~b}$ \\
\hline 8 & $37.10 \mathrm{bc}$ & $33.63 \mathrm{c}-\mathrm{e}$ & $31.90 \mathrm{e}-\mathrm{g}$ & $28.33 \mathrm{gh}$ & $32.74 \mathrm{~b}$ \\
\hline 12 & $36.00 \mathrm{~b}-\mathrm{d}$ & $28.83 \mathrm{f}-\mathrm{h}$ & $25.60 \mathrm{hi}$ & $22.07 \mathrm{i}$ & $28.13 \mathrm{c}$ \\
\hline \multirow[t]{2}{*}{ Mean } & $38.42 \mathrm{a}$ & $32.89 \mathrm{~b}$ & $31.37 \mathrm{~b}$ & $27.93 \mathrm{c}$ & \\
\hline & \multicolumn{5}{|c|}{ Relative water content (\%) } \\
\hline Control & $63.50 \mathrm{~g}$ & $69.63 \mathrm{f}$ & $71.50 \mathrm{ef}$ & 73.80de & $69.61 \mathrm{~d}$ \\
\hline 4 & $73.30 \mathrm{de}$ & 72.57 ef & $71.63 \mathrm{ef}$ & $73.67 \mathrm{de}$ & $72.79 \mathrm{c}$ \\
\hline 8 & $74.50 \mathrm{de}$ & $74.10 \mathrm{de}$ & $76.07 \mathrm{~cd}$ & $81.27 \mathrm{ab}$ & $76.48 \mathrm{~b}$ \\
\hline 12 & $77.80 \mathrm{c}$ & $78.57 \mathrm{bc}$ & $78.23 \mathrm{c}$ & $83.00 \mathrm{a}$ & $79.40 \mathrm{a}$ \\
\hline \multirow[t]{2}{*}{ Mean } & $72.28 \mathrm{c}$ & $73.72 b$ & $74.36 \mathrm{~b}$ & $77.93 \mathrm{a}$ & \\
\hline & \multicolumn{5}{|c|}{ Electrolyte leakage (\%) } \\
\hline Control & $57.33 \mathrm{a}$ & $41.67 b$ & $39.67 b$ & $33.60 \mathrm{~cd}$ & $43.07 \mathrm{a}$ \\
\hline 4 & $41.67 b$ & $35.00 \mathrm{c}$ & $33.83 \mathrm{~cd}$ & $33.03 \mathrm{~cd}$ & $35.88 \mathrm{~b}$ \\
\hline 8 & $40.50 \mathrm{~b}$ & $32.53 \mathrm{~cd}$ & $30.33 \mathrm{~d}$ & $26.00 \mathrm{e}$ & $32.34 \mathrm{c}$ \\
\hline 12 & $34.90 \mathrm{c}$ & $30.67 \mathrm{~cd}$ & $25.60 \mathrm{e}$ & $22.17 \mathrm{e}$ & $28.33 \mathrm{~d}$ \\
\hline Mean & $43.60 \mathrm{a}$ & $34.97 \mathrm{~b}$ & $32.37 \mathrm{c}$ & $28.70 \mathrm{~d}$ & \\
\hline
\end{tabular}

Mean values followed by the same letters are not significantly different at the $\mathbf{P}<0.05$ according to Duncan's multiple range test. 
Table 6. Effect of proline, yeast and their interaction on nitrogen, phosphor, potassium, calcium, magnesium and sodium (\% dry matter) in calendula leaves in the two seasons.

\begin{tabular}{|c|c|c|c|c|c|c|c|c|c|c|}
\hline \multirow{3}{*}{$\begin{array}{l}\text { Yeast } \\
\left(\mathrm{g} \mathrm{l}^{-1}\right)\end{array}$} & \multicolumn{5}{|c|}{ Proline (mg l' $\left.\mathrm{l}^{-1}\right)$} & \multicolumn{5}{|c|}{ Proline (mg l-1) } \\
\hline & Control & 50 & 75 & 100 & Mean & Control & 50 & 75 & 100 & Mean \\
\hline & \multicolumn{5}{|c|}{$1^{\text {st }}$ season } & \multicolumn{5}{|c|}{$2^{\text {nd }}$ season } \\
\hline & \multicolumn{10}{|c|}{ N (\%) } \\
\hline Control & $1.07 \mathrm{j}$ & $1.35 \mathrm{~h}$ & $1.48 \mathrm{f}$ & $1.73 \mathrm{~cd}$ & $1.41 \mathrm{~d}$ & 0.951 & $1.16 \mathrm{j}$ & $1.39 \mathrm{~g}$ & $1.42 \mathrm{fg}$ & $1.23 \mathrm{~d}$ \\
\hline 4 & $1.23 \mathrm{i}$ & $1.41 \mathrm{~g}$ & $1.61 \mathrm{e}$ & $1.62 \mathrm{e}$ & $1.47 \mathrm{c}$ & $1.04 \mathrm{k}$ & $1.23 \mathrm{i}$ & $1.42 \mathrm{fg}$ & $1.45 \mathrm{f}$ & $1.29 \mathrm{c}$ \\
\hline 8 & $1.42 \mathrm{~g}$ & $1.60 \mathrm{e}$ & $1.77 \mathrm{c}$ & $1.87 \mathrm{~b}$ & $1.67 \mathrm{~b}$ & $1.07 \mathrm{k}$ & $1.42 \mathrm{fg}$ & $1.58 \mathrm{~d}$ & $1.70 \mathrm{~b}$ & $1.44 b$ \\
\hline 12 & $1.58 \mathrm{e}$ & $1.69 \mathrm{~d}$ & $1.83 b$ & $1.97 \mathrm{a}$ & $1.78 \mathrm{a}$ & $1.32 \mathrm{~h}$ & $1.51 \mathrm{e}$ & $1.64 \mathrm{c}$ & $1.80 \mathrm{a}$ & $1.57 \mathrm{a}$ \\
\hline \multirow[t]{2}{*}{ Mean } & $1.32 \mathrm{~d}$ & $1.51 \mathrm{c}$ & $1.67 \mathrm{~b}$ & $1.80 \mathrm{a}$ & & $1.10 \mathrm{~d}$ & $1.33 \mathrm{c}$ & $1.51 \mathrm{~b}$ & $1.59 \mathrm{a}$ & \\
\hline & \multicolumn{10}{|c|}{$P(\%)$} \\
\hline Control & $0.147 \mathrm{j}$ & $0.195 \mathrm{i}$ & $0.224 \mathrm{gh}$ & $0.243 \mathrm{fg}$ & $0.202 \mathrm{c}$ & $0.118 n$ & $0.181 \mathrm{k}$ & $0.208 \mathrm{i}$ & $0.235 \mathrm{~g}$ & $0.186 \mathrm{~d}$ \\
\hline 4 & $0.185 \mathrm{i}$ & $0.214 \mathrm{~h}$ & $0.237 \mathrm{~g}$ & $0.277 \mathrm{de}$ & $0.228 b$ & $0.142 \mathrm{~m}$ & $0.196 \mathrm{j}$ & $0.225 \mathrm{~h}$ & $0.252 \mathrm{f}$ & $0.204 \mathrm{c}$ \\
\hline 8 & $0.217 \mathrm{~h}$ & $0.259 \mathrm{ef}$ & $0.294 b-d$ & $0.310 \mathrm{~b}$ & $0.270 \mathrm{a}$ & 0.1581 & $0.238 \mathrm{~g}$ & $0.278 \mathrm{~d}$ & $0.295 b$ & $0.242 b$ \\
\hline 12 & $0.189 \mathrm{i}$ & $0.286 \mathrm{~cd}$ & $0.303 \mathrm{bc}$ & $0.334 \mathrm{a}$ & $0.278 \mathrm{a}$ & $0.205 \mathrm{i}$ & $0.265 \mathrm{e}$ & $0.287 \mathrm{c}$ & $0.316 \mathrm{a}$ & $0.268 \mathrm{a}$ \\
\hline \multirow[t]{2}{*}{ Mean } & $0.184 d$ & $0.239 \mathrm{c}$ & $0.265 b$ & $0.291 \mathrm{a}$ & & $0.156 \mathrm{~d}$ & $0.220 \mathrm{c}$ & $0.249 b$ & $0.275 \mathrm{a}$ & \\
\hline & \multicolumn{10}{|c|}{ K (\%) } \\
\hline Control & $1.76 \mathrm{k}$ & $2.80 \mathrm{i}$ & $3.45 \mathrm{gh}$ & $3.73 \mathrm{e}-\mathrm{g}$ & $2.93 \mathrm{~d}$ & $1.34 \mathrm{o}$ & 2.491 & $3.28 \mathrm{i}$ & $3.69 \mathrm{~g}$ & $2.69 \mathrm{~d}$ \\
\hline 4 & $2.03 \mathrm{jk}$ & 3.10hi & $3.63 \mathrm{fg}$ & $4.02 \mathrm{c}-\mathrm{e}$ & $3.20 \mathrm{c}$ & $1.92 \mathrm{n}$ & $2.94 \mathrm{k}$ & $3.59 \mathrm{~h}$ & $3.87 \mathrm{ef}$ & $3.08 \mathrm{c}$ \\
\hline 8 & $2.38 \mathrm{j}$ & $3.83 \mathrm{~d}-\mathrm{f}$ & $4.19 b-d$ & $4.43 \mathrm{ab}$ & $3.71 b$ & $2.20 \mathrm{~m}$ & $3.78 \mathrm{fg}$ & $3.97 \mathrm{~cd}$ & $4.34 b$ & $3.57 b$ \\
\hline 12 & $3.15 \mathrm{q}$ & $4.14 b-d$ & $4.28 b c$ & $4.72 \mathrm{a}$ & $4.07 \mathrm{a}$ & $3.06 \mathrm{j}$ & $3.88 \mathrm{de}$ & $4.00 \mathrm{c}$ & $4.55 \mathrm{a}$ & $3.87 \mathrm{a}$ \\
\hline \multirow[t]{2}{*}{ Mean } & $2.33 \mathrm{~d}$ & $3.47 \mathrm{c}$ & $3.89 \mathrm{~b}$ & $4.22 \mathrm{a}$ & & $2.13 \mathrm{~d}$ & $3.27 \mathrm{c}$ & $3.71 \mathrm{~b}$ & $4.11 \mathrm{a}$ & \\
\hline & \multicolumn{10}{|c|}{$\mathrm{Na}(\%)$} \\
\hline Control & $2.55 \mathrm{a}$ & $2.25 \mathrm{~cd}$ & $2.06 \mathrm{ef}$ & $1.90 \mathrm{~g}$ & $2.19 \mathrm{a}$ & $2.70 \mathrm{a}$ & $2.36 \mathrm{c}$ & $2.10 \mathrm{e}$ & $1.96 \mathrm{f}$ & $2.28 \mathrm{a}$ \\
\hline 4 & $2.43 \mathrm{ab}$ & $2.20 \mathrm{cde}$ & $1.98 \mathrm{fg}$ & $1.73 \mathrm{hi}$ & $2.08 \mathrm{~b}$ & $2.48 \mathrm{~b}$ & $2.24 \mathrm{~d}$ & $2.04 \mathrm{ef}$ & $1.75 \mathrm{gh}$ & $2.13 b$ \\
\hline 8 & $2.31 b c$ & $1.86 \mathrm{gh}$ & $1.53 \mathrm{j}$ & $1.32 \mathrm{k}$ & $1.75 \mathrm{c}$ & $2.41 b c$ & $1.81 \mathrm{~g}$ & $1.65 \mathrm{ij}$ & $1.45 \mathrm{k}$ & $1.83 \mathrm{c}$ \\
\hline 12 & $2.13 \mathrm{de}$ & $1.67 \mathrm{i}$ & $1.43 \mathrm{jk}$ & 0.881 & $1.53 \mathrm{~d}$ & $2.22 \mathrm{~d}$ & 1.71hi & $1.59 \mathrm{j}$ & 1.011 & $1.63 \mathrm{~d}$ \\
\hline \multirow[t]{2}{*}{ Mean } & $2.36 \mathrm{a}$ & $2.00 \mathrm{~b}$ & $1.75 \mathrm{c}$ & $1.46 \mathrm{~d}$ & & $2.45 \mathrm{a}$ & $2.03 \mathrm{~b}$ & $1.85 \mathrm{c}$ & $1.54 \mathrm{~d}$ & \\
\hline & \multicolumn{10}{|c|}{$\mathrm{Ca}(\%)$} \\
\hline Control & $1.13 \mathrm{k}$ & $1.69 \mathrm{ij}$ & $2.05 \mathrm{~h}$ & $2.67 \mathrm{de}$ & $1.88 \mathrm{~d}$ & $1.31 \mathrm{n}$ & 1.731 & $2.12 \mathrm{i}$ & $2.64 \mathrm{e}$ & $1.95 \mathrm{~d}$ \\
\hline 4 & $1.58 \mathrm{j}$ & $1.97 \mathrm{~h}$ & $2.12 \mathrm{gh}$ & $2.74 \mathrm{~cd}$ & $2.10 \mathrm{c}$ & $1.44 \mathrm{~m}$ & $2.05 \mathrm{j}$ & $2.14 \mathrm{~h}$ & $2.73 \mathrm{~d}$ & $2.09 \mathrm{c}$ \\
\hline 8 & $1.76 \mathrm{i}$ & $2.43 \mathrm{f}$ & $2.84 \mathrm{c}$ & $3.28 \mathrm{ab}$ & $2.58 b$ & $2.01 \mathrm{k}$ & $2.21 \mathrm{f}$ & $2.93 \mathrm{c}$ & $3.07 \mathrm{~b}$ & $2.56 \mathrm{~b}$ \\
\hline 12 & $2.27 \mathrm{~g}$ & $2.54 \mathrm{ef}$ & $3.16 \mathrm{~b}$ & $3.42 \mathrm{a}$ & $2.84 \mathrm{a}$ & $2.19 \mathrm{~g}$ & $2.63 \mathrm{e}$ & $3.06 \mathrm{~b}$ & $3.28 \mathrm{a}$ & $2.79 \mathrm{a}$ \\
\hline \multirow[t]{2}{*}{ Mean } & $1.68 \mathrm{~d}$ & $2.16 \mathrm{c}$ & $2.54 b$ & $3.03 \mathrm{a}$ & & $1.74 \mathrm{~d}$ & $2.16 \mathrm{c}$ & $2.56 \mathrm{~b}$ & $2.93 \mathrm{a}$ & \\
\hline & \multicolumn{10}{|c|}{ Mg (\%) } \\
\hline Control & $0.166 \mathrm{j}$ & $0.172 \mathrm{j}$ & $0.212 \mathrm{hi}$ & $0.285 \mathrm{e}$ & $0.209 d$ & $0.163 \mathrm{i}$ & $0.173 \mathrm{i}$ & $0.208 \mathrm{~h}$ & $0.282 \mathrm{e}$ & $0.206 \mathrm{~d}$ \\
\hline 4 & $0.169 \mathrm{j}$ & $0.201 \mathrm{i}$ & $0.222 \mathrm{gh}$ & $0.296 \mathrm{de}$ & $0.222 \mathrm{c}$ & $0.167 \mathrm{i}$ & $0.205 \mathrm{~h}$ & $0.210 \mathrm{~h}$ & $0.307 \mathrm{~d}$ & $0.222 \mathrm{c}$ \\
\hline 8 & $0.176 \mathrm{j}$ & $0.264 f$ & $0.300 \mathrm{~d}$ & $0.475 b$ & $0.304 b$ & $0.202 \mathrm{~h}$ & $0.232 \mathrm{~g}$ & $0.315 \mathrm{~d}$ & $0.370 \mathrm{~b}$ & $0.280 \mathrm{~b}$ \\
\hline 12 & $0.224 \mathrm{~g}$ & $0.267 f$ & $0.345 \mathrm{c}$ & $0.512 \mathrm{a}$ & $0.337 \mathrm{a}$ & $0.213 \mathrm{~h}$ & $0.254 \mathrm{f}$ & $0.337 \mathrm{c}$ & $0.406 \mathrm{a}$ & $0.303 \mathrm{a}$ \\
\hline Mean & $0.184 d$ & $0.226 \mathrm{c}$ & $0.270 \mathrm{~b}$ & $0.392 \mathrm{a}$ & & $0.186 \mathrm{~d}$ & $0.216 \mathrm{c}$ & $0.268 b$ & $0.341 \mathrm{a}$ & \\
\hline
\end{tabular}

Mean values followed by the same letters are not significantly different at the $\mathbf{P}<\mathbf{0 . 0 5}$ according to Duncan's multiple range test. 


\section{Available elements content in the soil:}

The presented data in Table (7) indicated that available $\mathrm{N}, \mathrm{P}$ and $\mathrm{K} \mathrm{mg} \mathrm{kg}^{-1}$ in the soil after harvest significantly decreased with increasing the concentrations of proline and yeast in the two seasons. The highest values of $\mathrm{N}, \mathrm{P}$, and $\mathrm{K} \mathrm{mg} \mathrm{kg}{ }^{-1}$ in the soil after harvest were realized with control in the two seasons, respectively. Concerning the interactions between proline and yeast extract on available $\mathrm{N}, \mathrm{P}$, and $\mathrm{K}$ in the soil data presented in Table (7) showed that all the interaction treatments between proline and yeast extract had significant effects on $\mathrm{N}, \mathrm{P}$, and $\mathrm{K} \mathrm{mg} \mathrm{kg}^{-1}$. The lowest values of $\mathrm{N}$ (39.11 and $\left.33.74 \mathrm{mg} \mathrm{kg}^{-1}\right), \mathrm{P}(8.67 \& 8.33$ $\mathrm{mg} \mathrm{kg}^{-1}$ ) and $\mathrm{K}\left(241.92\right.$ and $\left.207.30 \mathrm{mg} \mathrm{kg}^{-1}\right)$ were recorded with the application of proline at $100 \mathrm{mg} \mathrm{l}^{-1}$ additional with yeast extract at $12 \mathrm{~g} \mathrm{l}^{-1}$, respectively in the two seasons.

\section{Anatomical characters:}

The anatomical characters of the leaves were presented in Table (8) and the cross sections are illustrated in Figs. (1 and 2). Our results revealed that the anatomical characters of calendula plants were decreased under salt stress conditions in control treatments (Fig. 1A). It is noted from Table (8) and Figs. (1 and 2) that spraying yeast extract and proline at various levels increased thickness of midvein, leaf lamina, palisade and spongy tissues as well as number of vessels/midvein bundle in saltstressed calendula plants, the best results were obtained with proline at $100 \mathrm{mg} \mathrm{l}^{-1}+$ yeast extract at $12 \mathrm{~g} \mathrm{l}^{-1}$.

\section{DISCUSSION}

In the present study, spraying Calendula officinalis plants with proline, yeast and their interaction improved morphological growth characters, floral parameters, photosynthetic pigments and nutrients \%, plant height, number of branches plant ${ }^{-1}$, and plant fresh and dry weights, number of flowers, flower diameter $(\mathrm{cm})$, flowers fresh and dry weights, vase life, chlorophyll, carotene, proline contents, $\mathrm{N}, \mathrm{P}, \mathrm{K}, \mathrm{Na}, \mathrm{Mg}$ and $\mathrm{Ca} \%$. It is clear from our results that the foliar application of proline and yeast extract significantly decreased the deleterious influences of salt stress. However, a higher concentration of proline $\left(100 \mathrm{mg} \mathrm{l}^{-1}\right)$ was more effective than levels of yeast on growth, but the best treatment was the interaction between proline at $100 \mathrm{mg} \mathrm{l}^{-1}$ and yeast at $12 \mathrm{~g} \mathrm{l}^{-1}$. Several previous studies reported that there was a positive relationship between plant growth and foliar application with proline and yeast under saline soil (Rady et al., 2016).

Application of yeast extract significantly decreased the harmful effects of salinity and enhanced all the vegetative and floral characters as well as chemical compounds in all concentrations especially $12 \mathrm{~g} \mathrm{l}^{-1}$. These results are similar to those observed in calendula plants by Nofal et al. (2015) who indicated that using yeast extract as a foliar application under saline and non-saline treatments led to improve growth and appeared appropriate variations in the stem and the leaf anatomical structure as affected by salinity. The stimulation influence of dry yeast on plant growth is due to that the active dry yeast is wealthy with vitamins, amino acids and proteins. There was a gradual increment in all morphological growth characters (plant height, number of branches, leaf number, leaf area and leaves dry weight) as well as chemical characters by adding active dry yeast (Matter and Abou-Sreea, 2016) in fenugreek plants. Foliar application of yeast extract significantly increased all morphological characters and yield as well as improved the anatomical characters of the major stem and leaves particularly the phloem and xylem tissues (Nassar et al., 2015) on Ocimum basilicum.

In the present investigation, it was observed that the exogenous application of proline, particularly the level of $100 \mathrm{mg} \mathrm{l}^{-1}$ significantly enhanced endogenous proline levels in calendula plants, reduced the harmful effects of salinity stress and consequently improved calendula growth, flowering and related characters. This result is due to that proline has been absorbed by 
Table 7. Effect of proline, yeast and their interaction on soil available nitrogen, phosphor and potassium (mg kg-1) in the soil at harvest stage of calendula plants in the two seasons.

\begin{tabular}{|c|c|c|c|c|c|c|c|c|c|c|}
\hline \multirow{3}{*}{$\begin{array}{l}\text { Yeast } \\
\left(\mathrm{g} \mathrm{l}^{-1}\right)\end{array}$} & \multicolumn{5}{|c|}{ Proline $\left(\mathrm{mg} \mathrm{l}^{-1}\right)$} & \multicolumn{5}{|c|}{ Proline $\left(\mathrm{mg} \mathrm{l}^{-1}\right)$} \\
\hline & Control & 50 & 75 & 100 & Mean & Control & 50 & 75 & 100 & Mean \\
\hline & \multicolumn{5}{|c|}{$1^{\text {st }}$ season } & \multicolumn{5}{|c|}{$2^{\text {nd }}$ season } \\
\hline & \multicolumn{10}{|c|}{$\mathrm{N}\left(\mathrm{mg} \mathrm{kg} \mathbf{k g}^{-1}\right)$} \\
\hline Control & $44.03 \mathrm{a}$ & $43.67 \mathrm{~cd}$ & $43.83 b$ & $39.88 \mathrm{k}$ & $42.85 \mathrm{a}$ & $43.26 \mathrm{a}$ & $39.71 \mathrm{~b}$ & $38.88 b c$ & $38.35 b c$ & $40.05 a$ \\
\hline 4 & $43.77 \mathrm{bc}$ & $43.60 \mathrm{~d}$ & $43.34 \mathrm{e}$ & 39.681 & $42.60 \mathrm{~b}$ & $39.08 \mathrm{bc}$ & $38.71 b c$ & $38.66 \mathrm{bc}$ & $37.81 \mathrm{c}$ & $38.56 b$ \\
\hline 8 & $42.81 \mathrm{f}$ & $42.30 \mathrm{~g}$ & $42.00 \mathrm{~h}$ & $39.22 \mathrm{~m}$ & $41.58 \mathrm{c}$ & $38.58 \mathrm{bc}$ & $38.49 \mathrm{bc}$ & $38.48 \mathrm{bc}$ & $35.39 d$ & $37.74 \mathrm{c}$ \\
\hline 12 & $41.11 \mathrm{i}$ & $40.22 \mathrm{j}$ & $40.17 \mathrm{j}$ & $39.11 \mathrm{~m}$ & $40.15 d$ & $38.44 \mathrm{bc}$ & $38.41 \mathrm{bc}$ & $38.37 \mathrm{bc}$ & $33.74 \mathrm{e}$ & $37.24 \mathrm{c}$ \\
\hline \multirow[t]{2}{*}{ Mean } & $42.93 \mathrm{a}$ & $42.45 b$ & $42.34 \mathrm{c}$ & $39.47 d$ & & $39.84 \mathrm{a}$ & $38.83 b$ & $38.60 \mathrm{~b}$ & $36.32 \mathrm{c}$ & \\
\hline & \multicolumn{10}{|c|}{$P\left(\mathrm{mg} \mathrm{kg}^{-1}\right)$} \\
\hline Control & $13.83 \mathrm{a}$ & $13.67 \mathrm{a}$ & $12.33 b$ & $10.83 \mathrm{ef}$ & $12.42 \mathrm{a}$ & $12.67 \mathrm{a}$ & $12.50 \mathrm{a}$ & $11.83 \mathrm{~b}$ & $9.33 \mathrm{ef}$ & $11.58 \mathrm{a}$ \\
\hline 4 & $12.00 \mathrm{c}$ & $12.00 \mathrm{c}$ & $11.33 \mathrm{~d}$ & $10.67 \mathrm{fg}$ & $11.50 \mathrm{~b}$ & $11.67 \mathrm{~b}$ & $11.00 \mathrm{c}$ & $10.33 \mathrm{~d}$ & $9.00 \mathrm{f}$ & $10.50 \mathrm{~b}$ \\
\hline 8 & $11.17 \mathrm{de}$ & $10.67 \mathrm{fg}$ & $10.33 \mathrm{~g}$ & $9.33 \mathrm{i}$ & $10.38 \mathrm{c}$ & $10.17 \mathrm{~d}$ & $9.50 \mathrm{e}$ & $9.33 \mathrm{ef}$ & $8.83 \mathrm{~g}$ & $9.33 \mathrm{c}$ \\
\hline 12 & $10.50 \mathrm{fg}$ & $9.83 \mathrm{~h}$ & $9.33 \mathrm{i}$ & $8.67 \mathrm{j}$ & $9.58 \mathrm{~d}$ & $9.33 \mathrm{~h}$ & $9.50 \mathrm{i}$ & $9.33 \mathrm{i}$ & $8.33 \mathrm{j}$ & $9.12 \mathrm{~d}$ \\
\hline \multirow[t]{2}{*}{ Mean } & $12.13 \mathrm{a}$ & $11.79 \mathrm{~b}$ & $11.08 \mathrm{c}$ & $9.88 \mathrm{~d}$ & & $10.96 \mathrm{a}$ & $10.62 \mathrm{~b}$ & $10.20 \mathrm{c}$ & $8.87 \mathrm{~d}$ & \\
\hline & \multicolumn{10}{|c|}{$K\left(\mathrm{mg} \mathrm{kg}{ }^{-1}\right)$} \\
\hline Control & $318.68 \mathrm{a}$ & $310.73 \mathrm{ab}$ & $281.07 \mathrm{c}$ & $252.38 \mathrm{~h}-\mathrm{j}$ & $290.71 \mathrm{a}$ & $303.88 \mathrm{a}$ & $296.75 \mathrm{~b}$ & $284.33 c$ & $227.68 \mathrm{hi}$ & $278.16 \mathrm{a}$ \\
\hline 4 & $308.58 b$ & $306.32 b$ & $262.48 \mathrm{ef}$ & $248.72 \mathrm{i}-\mathrm{k}$ & $285.74 b$ & $288.97 \mathrm{c}$ & $269.85 \mathrm{~d}$ & $267.90 \mathrm{~d}$ & $226.42 \mathrm{hi}$ & $263.28 b$ \\
\hline 8 & $276.47 \mathrm{~cd}$ & $268.83 \mathrm{de}$ & $261.33 \mathrm{e}-\mathrm{g}$ & $248.13 \mathrm{jk}$ & $264.60 c$ & $245.90 \mathrm{e}$ & $240.13 \mathrm{ef}$ & $238.17 \mathrm{fg}$ & $220.83 i$ & $236.26 \mathrm{c}$ \\
\hline 12 & $259.12 \mathrm{f}-\mathrm{h}$ & $257.08 \mathrm{f}-\mathrm{i}$ & $253.52 \mathrm{~g}-\mathrm{j}$ & $241.92 \mathrm{k}$ & $247.79 d$ & $236.98 \mathrm{fg}$ & $235.85 \mathrm{fg}$ & $232.33 \mathrm{gh}$ & $207.30 \mathrm{j}$ & $228.12 d$ \\
\hline Mean & $290.72 a$ & $281.53 b$ & $263.69 c$ & $252.91 d$ & & $268.93 a$ & $260.65 a$ & $255.68 b$ & $220.56 \mathrm{c}$ & \\
\hline
\end{tabular}

Mean values followed by the same letters are not significantly different at the $P<0.05$ according to Duncan's multiple range test.

Table 8. Effect of proline and yeast extract on anatomical leaf structure of calendula plants under salt stress conditions in the second season.

\begin{tabular}{|c|c|c|c|c|c|c|}
\hline \multirow[b]{2}{*}{ Treatments } & \multicolumn{6}{|c|}{ Anatomical characters of leaves } \\
\hline & $\begin{array}{c}\text { Midvein } \\
\text { thickness } \\
(\mu)\end{array}$ & $\begin{array}{c}\text { Leaf } \\
\text { lamina } \\
\text { thickness } \\
(\mu) \\
\end{array}$ & $\begin{array}{c}\text { Palisade } \\
\text { tissue } \\
(\mu)\end{array}$ & $\begin{array}{l}\text { Spongy } \\
\text { tissue } \\
(\mu)\end{array}$ & $\begin{array}{c}\text { Vessels } \\
\text { No/midvein } \\
\text { bundle }\end{array}$ & $\begin{array}{c}\text { Vessel } \\
\text { diameter } \\
(\mu)\end{array}$ \\
\hline Control & 1336.0 & 384.5 & 106.9 & 241.0 & 32.6 & 21.0 \\
\hline Proline 50 mg l$^{-1}$ & 1368.2 & 391.0 & 111.2 & 256.7 & 39.0 & 25.0 \\
\hline Proline $75 \mathrm{mg} \mathrm{l}^{-1}$ & 1423.5 & 417.6 & 106.8 & 262.0 & 41.8 & 22.6 \\
\hline Proline100 $\mathrm{mg} \mathrm{l}^{-1}$ & 1475.6 & 429.0 & 116.0 & 268.0 & 42.0 & 26.0 \\
\hline Yeast $4 \mathrm{~g} \mathrm{l}^{-1}$ & 1384.0 & 396.0 & 108.0 & 259.0 & 40.0 & 25.0 \\
\hline Yeast $8 \mathrm{~g} \mathrm{l}^{-1}$ & 1519.0 & 403.5 & 109.6 & 263.6 & 36.0 & 24.2 \\
\hline Yeast $12 \mathrm{~g} \mathrm{l}^{-1}$ & 1682.0 & 449.0 & 118.0 & 279.8 & 39.0 & 26.0 \\
\hline Proline $50 \mathrm{mg} \mathrm{l}^{-1}+$ yeast $4 \mathrm{~g} \mathrm{l}^{-1}$ & 1671.3 & 431.7 & 115.0 & 267.0 & 41.0 & 26.0 \\
\hline Proline $75 \mathrm{mg} \mathrm{l}^{-1}+$ yeast $4 \mathrm{~g} \mathrm{l}^{-1}$ & 1658.0 & 427.0 & 117.0 & 272.9 & 38.2 & 25.5 \\
\hline Proline $100 \mathrm{mg} \mathrm{l}^{-1}+$ yeast $4 \mathrm{~g} \mathrm{l}^{-1}$ & 1674.5 & 438.0 & 116.6 & 278.4 & 41.0 & 24.8 \\
\hline Proline $50 \mathrm{mg} \mathrm{l}^{-1}+$ yeast $8 \mathrm{~g} \mathrm{l}^{-1}$ & 1672.7 & 448.0 & 119.4 & 286.0 & 40.0 & 23.9 \\
\hline Proline $75 \mathrm{mg} \mathrm{l}^{-1}+$ yeast $8 \mathrm{~g} \mathrm{l}^{-1}$ & 1685.0 & 457.0 & 121.0 & 284.0 & 43.0 & 26.0 \\
\hline Proline $100 \mathrm{mg} \mathrm{l}^{-1}+$ yeast $8 \mathrm{~g} \mathrm{l}^{-1}$ & 1724.0 & 468.0 & 125.0 & 287.0 & 39.4 & 25.0 \\
\hline Proline $50 \mathrm{mg} \mathrm{l}^{-1}+$ yeast $12 \mathrm{~g} \mathrm{l}^{-1}$ & 1732.4 & 482.6 & 126.5 & 291.3 & 40.0 & 26.0 \\
\hline Proline $75 \mathrm{mg} \mathrm{l}^{-1}+$ yeast $12 \mathrm{~g} \mathrm{l}^{-1}$ & 1745.0 & 507.0 & 137.0 & 296.0 & 43.0 & 25.5 \\
\hline Proline $100 \mathrm{mg} \mathrm{l}^{-1}+$ yeast $12 \mathrm{~g} \mathrm{l}^{-1}$ & 1776.2 & 513.0 & 135.0 & 302.0 & 44.0 & 26.4 \\
\hline
\end{tabular}




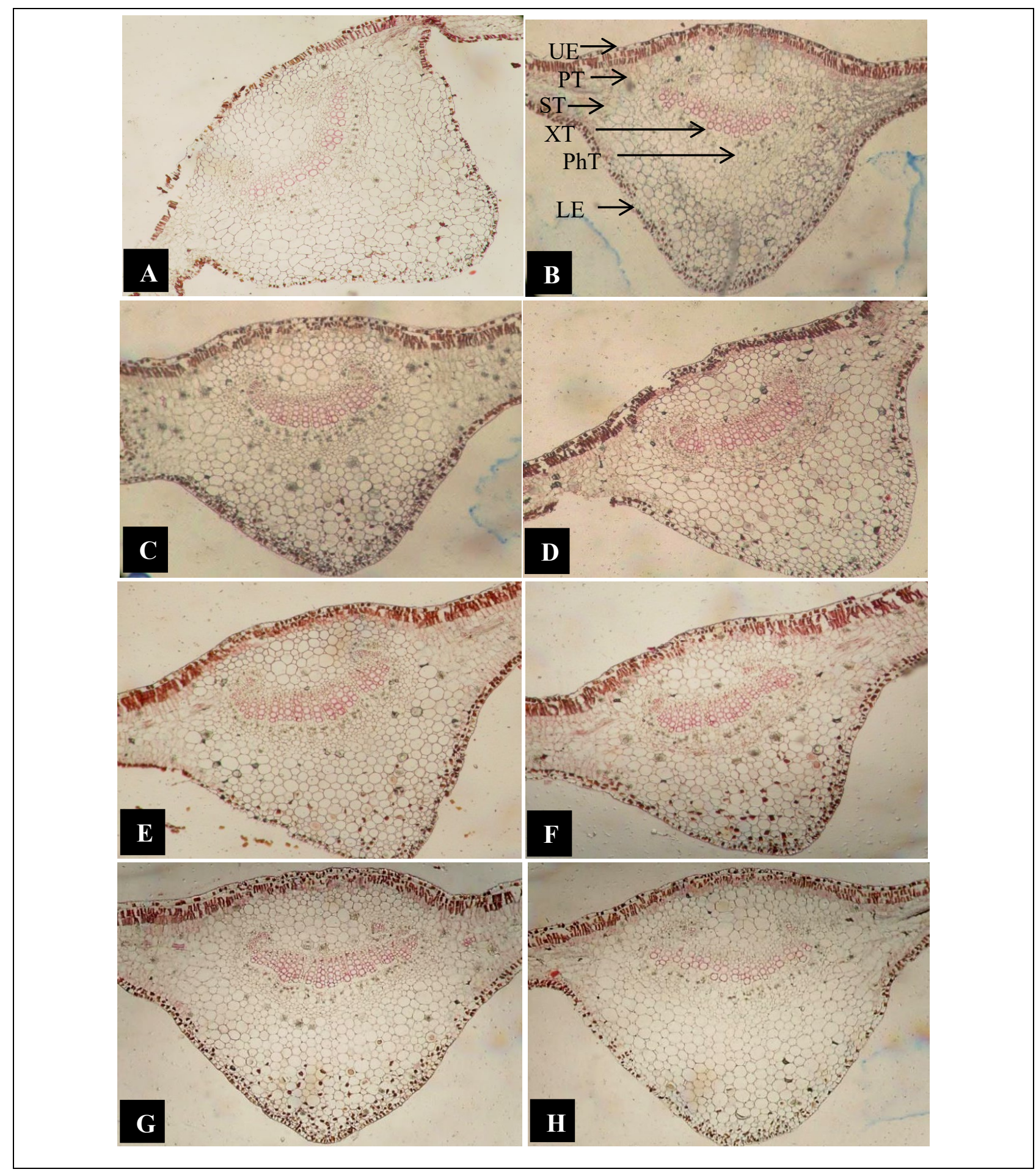

Fig. 1. Transverse sections of calendula leaves.

A. Control (salt stressed untreated plants), B. Proline $50 \mathrm{mg} \mathrm{l}^{-1}$, C. Proline $75 \mathrm{mg} \mathrm{l}^{-1}$, D. Proline100 $\mathrm{mg} \mathrm{l}^{-1}, \mathrm{E}$. Yeast $4 \mathrm{~g} \mathrm{l}^{-1}, \mathrm{~F}$. Yeast $8 \mathrm{~g} \mathrm{l}^{-1}$, G. Yeast $12 \mathrm{~g} \mathrm{l}^{-1}$, H. Proline $50 \mathrm{mg} \mathrm{l}^{-1}+$ yeast $4 \mathrm{~g} \mathrm{l}^{-1}$ (X 100), UE. Upper epidermis, PT. Palisade tissue, ST. Spongy tissue, XT. Xylem tissue, PhT. Phloem tissue, LE. Lower epidermis. 


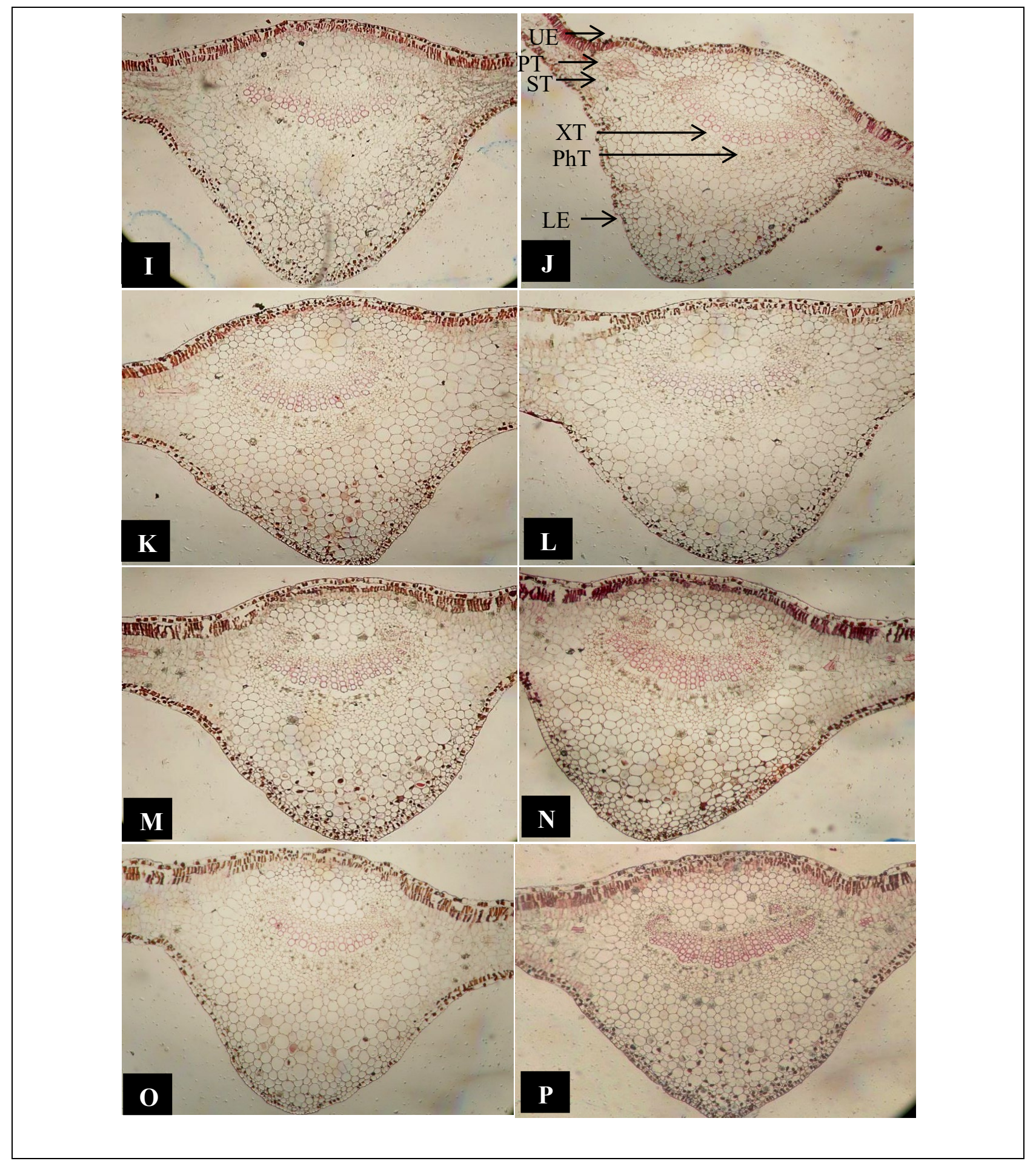

Fig. 2. Transverse sections of calendula leaves.

I. Proline $75 \mathrm{mg} \mathrm{l}^{-1}+$ yeast $4 \mathrm{~g} \mathrm{l}^{-1}$, J. Proline $100 \mathrm{mg} \mathrm{l}^{-1}+$ yeast $4 \mathrm{~g} \mathrm{l}^{-1}$, $\mathrm{K}$. Proline $50 \mathrm{mg} \mathrm{l}^{-1}+$ yeast $8 \mathrm{~g} \mathrm{l}^{-1}, \mathrm{~L}$. Proline $75 \mathrm{mg} \mathrm{l}^{-1}+$ yeast $8 \mathrm{~g} \mathrm{l}^{-1}$, M. Proline $100 \mathrm{mg} \mathrm{l}^{-1}+$ yeast $8 \mathrm{~g} \mathrm{l}^{-1}$, $\mathrm{N}$. Proline $50 \mathrm{mg} \mathrm{l}^{-1}+$ yeast $12 \mathrm{~g} \mathrm{l}^{-1}, \mathrm{O}$. Proline $75 \mathrm{mg} \mathrm{l}^{-1}+$ yeast $12 \mathrm{~g} \mathrm{l}^{-1}$, P. Proline $100 \mathrm{mg} \mathrm{l}^{-1}+$ yeast $12 \mathrm{~g} \mathrm{l}^{-1}$ (X 100), UE. Upper epidermis, PT. Palisade tissue, ST. Spongy tissue, XT. Xylem tissue, PhT. Phloem tissue, LE. Lower epidermis. 
the plant, where it preserved water state by increasing water flow and decreasing the outflow of water under salt stress conditions (Chen and Murata, 2008). Moreover, proline safeguards cell membranes against saltinduced oxidative stress, ion toxicity and increased cellular growth (Banu et al., 2009). The previous studies indicated that the exogenous application of proline significantly ameliorates the deleterious effects of salinity (Siddique et al., 2015). Likewise, proline had a significant role in growth characteristics, yield and physiological characteristics (Rady et al., 2016 on lupine plants). Salt stress induced a significant reduction in chlorophyll and carotenoids concentrations in calendula plants, these results are due to the inhibition of PSII activity and reduction of chlorophylls and $\mathrm{CO}_{2}$ assimilation in leaves as a result of the toxic ions accumulation (Oyiga et al., 2016). The reduction in chlorophyll concentration was recorded under various stresses (Abdelaal et al., 2018).

Results indicated also that total chlorophyll in the leaves and carotene concentration in flowers showed an increase with proline at $100 \mathrm{mg}^{-1}$. These increases in chlorophyll are attributed to activating chlorophyll biosynthesis and/or preventing its degradation. Furthermore, these results attributed to the more effective scavenging of ROS with proline and other antioxidant compounds (Abdelhamid et al., 2013). Also, Cirillo et al. (2016) reported that ornamental shrubs treated with either glycine betaine or proline led to enhance chlorophyll concentration. This is attributed to an increment in the chloroplast membranes stabilization or the preservation of photosystem using osmoprotectant molecules.

Salt stress is one of the significant abiotic factors affecting physiological and biochemical characters and one of the main limits for plant production. The exposure of calendula plants to salt stress is associated with increasing antioxidant enzymes activity, mainly catalase, peroxidase and polyphenol oxidase (Table, 5). The increase in enzymes activity may point to the efficiency of these antioxidant enzymes in scavenging and detoxification of reactive oxygen species such as superoxide and hydrogen peroxide, consequently protect calendula plant against oxidative stress. These results are similar to the obtained results of Cia et al. (2012) in sugarcane plants. With the same trend, the antioxidant enzymes up-regulation improved plant tolerance under salt stress conditions in sweet potato plants (Yan et al., 2016). In the current study, electrolyte leakage (EL) was significantly increased in the salt-stressed plants, this increment of EL can be ascribed to the harmful effects of salt stress on the plasma membrane which resulted in an increase in membrane permeability (Tiwari et al., 2010). The same trend was recorded with El-Banna and Abdelaal (2018) and Faghih et al. (2018). This negative effect of salt stress on calendula plasma membrane due to the high accumulation of reactive oxygen species under salt stress conditions led to oxidative damage. Furthermore, salt stress led to a significant decrease in relative water content in stressed plants because of the injurious effect of salinity on root cell wall structure and cell elongation (Byrt et al., 2018). These results are similar to the obtained results with Mickky et al. (2019) and Roy et al. (2019). Application of proline and yeast extract individually or in combination led to improve the upregulation of catalase, peroxidase and polyphenol oxidase activities in salt-stressed plants. Additionally, relative water content was increased with the application of these treatments (Table, 5). The interaction between proline and yeast extract was more effective compared with individual foliar applications, the best treatment was proline at $100 \mathrm{mg} \mathrm{l}^{-1}+$ yeast at $12 \mathrm{~g} \mathrm{l}^{-1}$. With the same trend, Ahmed et al. (2010) indicated that proline treatment led to improve activities of antioxidant enzymes, photosynthetic rate and consequently enhanced plant growth in olive trees under salt stress conditions due to the osmoprotective role of proline. The valuable 
effects of yeast due its role as a natural source of vitamins and amino acids that encourage protein synthesis, chlorophyll formation (Abdelaal, 2015b) and improve plant growth as well as increase fungal stress tolerance (Bevilacqua et al., 2008). Application of proline and yeast had a significant effect on electrolyte leakage, the obtained results indicated that EL was decreased with all treatments compared with control plants. Electrolyte leakage is an indicator to various stresses in plant tissues. The most reduction in EL was recorded with proline at $100 \mathrm{mg} \mathrm{l}^{-1}+$ yeast at $12 \mathrm{~g} \mathrm{l}^{-1}$ followed by proline at $75 \mathrm{mg}^{-1}+$ yeast at 12 $\mathrm{g}^{-1}$ (Table, 5). This result is attributed to the active role of proline inactivation of antioxidant enzymes, protect protein and decreased MDA (Chutipaijit et al., 2009) consequently, decreased electrolyte leakage. Results showed also that yeast extract has a pivotal role on the EL due to the various nutrients and vitamins as well as amino acids in yeast extract which improves water status of plant cells and membrane stability.

The increase in ROS levels (superoxide and hydrogen peroxide) under salt conditions in salt-stressed calendula plants (Table, 5) due to the adverse effect of salt stress which, causes oxidative damage to mitochondria, chloroplast and peroxisomes under abiotic stress. This result is agreed with the result of Hasegawa et al. (2000). Foliar application of proline and yeast led to improve plant growth and decrease superoxide and hydrogen peroxide levels. This result of proline treatment is due to the role of proline in ROS scavenging and inducing salt tolerance in calendula plants. This result is similar to the results of Khedr et al. (2003) and Hoque et al. (2008) who reported the role of proline inactivation of the enzymatic antioxidant defense system, consequently, increases salt tolerance in various plants. Likewise, the valuable effect of yeast on ROS scavenging due to its pivotal role in plant growth improvement under stresses. These results are in line with those recorded with Abdelaal et al. (2017) under drought stress.
The results in the present study indicated that salinity was associated with decreasing in $\mathrm{N}, \mathrm{P}, \mathrm{K}, \mathrm{Mg}$ and $\mathrm{Ca} \%$, while increasing $\mathrm{Na} \%$ in the leaves. These results are in agreement with El-Shawa and Elzohiry, (2018) on roses. This is due to that high $\mathrm{Na}$ in the soil caused a deficiency of other nutrients by preventing the uptake of nutrients immediately by interfering with the carrier in the root plasma membrane, like Kselective ion canals, and prevent root growth by the osmotic effects of $\mathrm{Na}$ and because of the detrimental effects of $\mathrm{Na}$ on soil structure (Tester and Daveport, 2003). The results showed that there is decreasing in $\mathrm{Na}^{+}$, while increasing $\mathrm{N}, \mathrm{P}, \mathrm{K}, \mathrm{Mg}$ and $\mathrm{Ca}$ in plant, this is due to the exogenous application of proline which alleviates the negative effect of salinity and protects the plant cells by osmotic adjustment (Hoque et al., 2007). Similar results were obtained by Abdelhamid et al. (2013) in Phaseolus vulgaris L. Results also indicated that application of proline, yeast and their interaction significantly decreased available ( $\mathrm{N}, \mathrm{P}$ and $\mathrm{K} \mathrm{mg} \mathrm{kg}^{-1}$ ) in the soil. This is maybe due to the application of proline, yeast and their interaction, which led to an increase in plant growth, thus the plant absorb more nutrients from the soil more than untreated plants and decrease in the soil's content of elements after harvest.

According to the microscopic measurements in (Table, 8) and micrographs in Figures (1 and 2) the exposed plants to salt stress showed a decrease in anatomical characters of the leaves, as the adverse effect of salt stress due to the negative role of salinity on the growth and physiological characters of calendula plants. Similar results were recorded under various stresses in many plants (Abdelaal, 2015a and Dawood et al., 2014). These results could be mainly attributed to the pivotal role of yeast and proline in improvement the morphological characters consequently enhance the anatomical structure of leaves in salt-stressed calendula plants (Figs. 1 and 2). The effective role of proline and yeast on the anatomical structure of leaves in stressed 
plants was recorded by Dawood et al. (2014) and Nassar et al. (2016).

\section{CONCLUSION}

It can be concluded that spraying Calendula officinalis plants with proline or yeast extract were highly efficient on mitigating the harmful effect of salty soil. Also, foliar application of proline at 100 $\mathrm{mg} \mathrm{l}^{-1}+$ yeast extract at $12 \mathrm{~g} \mathrm{l}^{-1}$ followed by proline at $75 \mathrm{mg} \mathrm{l}^{-1}+$ yeast extract at $12 \mathrm{~g} \mathrm{l}^{-1}$ were the highest treatments to increase the tolerance of calendula to salt stress. So, it can recommend that using proline at 100 $\mathrm{mg}^{-1}+$ yeast extract at $12 \mathrm{~g}^{-1}$ can mitigate the harmful effects of soil salt stress on Calendula officinalis and improve the growth and anatomical characters as well as flowers production.

\section{REFERENCES}

Abdelaal, Kh.A.A. (2015a). Effect of salicylic acid and abscisic acid on morpho-physiological and anatomical characters of faba bean plants (Vicia faba L.) under drought stress. J. Plant Production, Mansoura Univ., Egypt, 6(11): 1771-1788.

Abdelaal, Kh.A.A. (2015b). Pivotal role of bio and mineral fertilizer combinations on morphological, anatomical and yield characters of sugar beet plant (Beta vulgaris L.). Middle East J. Agric., 4:717-734.

Abdelaal, Kh.A.A.; Hafez, Y.M.; El Sabagh, A. and Saneok, H. (2017). Ameliorative effects of abscisic acid and yeast on morpho-physiological and yield characteristics of maize plant (Zea mays L.) under water deficit conditions. Fresenius Environmental Bulletin, 26(12):7372-7383.

Abdelaal, Kh.A.A.; Hafez, Y.M.; El-Afry, M.M.; Tantawy, D.S. and Alshaal, T. (2018). Effect of some osmoregulators on photosynthesis, lipid peroxidation, antioxidative capacity, and productivity of barley (Hordeum vulgare L.) under water deficit stress. Environmental
Science and Pollution Research, 25:30199-30211.

Abdelaal, Kh.A.A.; Attia, K.; Alamery, S.F.; El-Afry, M.M.; Ghazy A.I.; Tantawy, D.; Al-Doss, A.; El-Shawy, E.L.; AbuElsaoud, A.M.; and Hafez, Y.M. (2020a). Exogenous application of proline and salicylic acid can mitigate the injurious impacts of drought stress on barley plants associated with physiological and histological characters. Sustainability, 12(5): 1736.

Abdelaal, Kh.A.A.; EL-Maghraby, L.M.; Elansary, H.; Hafez, Y.M.; Ibrahim, E.I.; El-Banna, M.; El-Esawi, M. and Elkelish, A. (2020b). Treatment of sweet pepper with stress tolerance-inducing compounds alleviates salinity stress oxidative damage by mediating the physio-biochemical activities and antioxidant systems. Agronomy, 10(26):1-15. http://dx.doi.org/10.3390/ agronomy 10010026

Abdelhamid, M.T.; Rady, M.M.; Osman, A.S. and Abdalla, M.A. (2013). Exogenous application of proline alleviates salt-induced oxidative stress in Phaseolus vulgaris L. plants. J. of Horti. Sci. and Biotech., 88: 439-446.

Adam A.; Farkas, T.; Somlyai, G.; Hevesi, M. and Király, Z. (1989). Consequence of $\mathrm{O}_{2}^{-}$generation during a bacterially induced hypersensitive reaction in tobacco. Deterioration of membrane lipids. Physiol. Mol. Plant Pathol., 34:1326.

Aebi, H.E. (1983). Catalase. In: Bergmeyer, H. (ed.), Methods of Enzymatic Analysis, $3^{\text {rd }}$ Ed. Verlag Chemie, Weinheim, Germany, pp. 273-286.

Ahmed, B.C.; Rouina, B.B.; Sensoy, S.; Boukhriss, M. and Abdullah, B.F. (2010). Exogenous proline effects on photosynthetic performance and antioxidant defense system of young olive tree. J. Agri. and Food Chem., 58(7): 4216-4122. 
Amer, S.S.A. (2004). Growth, green pods yield and seeds yield of common bean (Phaseolus vulgaris L.) as affected by active dry yeast, salicylic acid and their interaction. J. Agri. Sci. Mansoura Univ., 29(3): 1407-1422.

A.O.A.C. (1990). Official Methods of the Analytical Chemist., 15 ${ }^{\text {th }}$ Ed., Vol. 2. Arlington, Virginia, USA., 1298 p.

Banu, N.A.; Hoque, A.; WatanabeSugimoto, M.; Matsuoka, K.; Nakamura, Y.; Shimoishi,Y. and Murata, Y. (2009). Proline and glycinebetaine induce antioxidant defense gene expression and suppress cell death in cultured tobacco cells under salt stress. J. Plant Physiol.,166(2):146-156.

Bates, L.S. (1973). Rapid determination of free proline for water-stress studies. Plant Soil, 39: 205-207.

Bayat, H.; Alirezaie, M. and Neamati, H. (2012). Impact of exogenous salicylic acid on growth and ornamental characteristics of calendula (Calendula officinalis L.) under salinity stress. J. Stress Physiol. and Biochem., 8(1):258267.

Bevilacqua, A.; Corbo, M.R.; Mastromatteo, M. and Sinigaglia, M. (2008). Combined effects of $\mathrm{pH}$, yeast extract, carbohydrates and di-ammonium hydrogen citrate on the biomass production and acidifying ability of a probiotic Lactobacillus plantarum strain, isolated from table olives, in a batch system. World J. Microb. Biot., 24:17211729.

Byrt, C.S.; Munns, R.; Burton, R.A.; Gilliham, M. and Wege, S. (2018). Root cell wall solutions for crop plants in saline soils. Plant Science, 269: 47-55.

Chen, T.H.H. and Murata, N. (2008). Glycine betaine. an effective protectant against abiotic stress in plants. Trends in Plant Science, 13: 499-505.

Chutipaijit, S.; Suriyan, C. and Kanokporn, S. (2009). Differential accumulations of proline and flavonoids in indica rice varieties against salinity. Pak. J. Bot., 41:2497-2506.

Cia, M.C.; Guimarães, A.C.R.; Medici, L.O.; Chabregas, S.M. and Azevedo, R.A. (2012). Antioxidant responses to water deficit by drought-tolerant and -sensitive sugarcane varieties. Annals of Applied Biology, 161: 313-324.

Cirillo, C.; Rouphael, Y.; Caputo, R.; Raimondi, G.; Sifola, M.I. and Pascale, S.D. (2016). Effects of high salinity and the exogenous application of an osmolyte on growth, photosynthesis, and mineral composition in two ornamental shrubs. J. Hort. Sci. and Biotechnology, 91(1):1422.

Cottenie, A.; Verloo, M.; Kiekens, L. and Canerlynck, R. (1982). Chemical Analysis of Plants and Soil. Laboratory of Analysis and Agrochemistry. State Univ. Ghent, Belgium.

Dawood, M.G.; Taieb, H.A.A.; Abdelhamida, M.T. and Schmidhalterd, U. (2014). The changes induced in the physiological, biochemical and anatomical characteristics of Vicia faba by the exogenous application of proline under seawater stress. South African Journal of Botany, 93: 54-63.

Dewis, J. and Fertias, F. (1970). Physical and chemical methods of soil and water analysis. Soils Bulletin, No. 10. Rome, FAO., 275 p.

Dionisio-Sese, M.L. and Tobita, S. (1998). Antioxidant responses of rice seedlings to salt stress. Plant Science, 135: 1-9.

Duncan, D.B. (1955). Multiple range and multiple F tests. Biometrics, 11:1-42.

El-Banna, M.F. and Abdelaal, Kh. A.A. (2018). Response of strawberry plants grown in the hydroponic system to pretreatment with $\mathrm{H}_{2} \mathrm{O}_{2}$ before exposure to salinity stress. J. Plant Production, Mansoura Univ., 9: 989-1001. 
El-Gamal Seham, M.A. (2015). Influence of pinching and potassium sources on growth and flowers yield of Calendula officinalis. Egypt. J. Hort. 42(1):639654.

El-Shawa, Ghada M.R. and Elzohiry, Nahla A. (2018). Mitigation the harmful effect of irrigation water salinity on Rosa hybirida, cv. Centrix by using arginine and magnetic iron. Scientific J. Flowers and Ornamental Plants, 5(4):293-308.

Faghih, S.; Zarei, A. and Ghobadi, C. (2018). Positive effects of plant growth regulators on physiology responses of Fragaria $\times$ ananassa $\mathrm{cv}$. Camarosa under salt stress. International $J$. of Fruit Science, 4: 1-11.

Gomez, K.A. and Gomez, A.A. (1984). Statistical Procedures for Agricultural Research. $2^{\text {nd }}$ ed. International Rice Research Institute, College, Laguna, $680 \mathrm{p}$.

Hafez, Y.M.; Attia, K.A.; Alamery, S.; Ghazy, A.; Al-Dosse, A.; Ibrahim, E.; Rashwan, E.; El-Maghraby, L.; Awad, A. and Abdelaal, Kh. A.A. (2020). Beneficial effects of biochar and chitosan on antioxidative capacity, osmolytes accumulation, and anatomical characters of water-stressed barley plants. Agronomy, 10(630):1-18. http://dx.doi. org/10.3390/agronomy 10050630

Hammerschmidt, R.; Nuckles, E.M. and Kuc, J. (1982). Association of enhanced peroxidase activity with induced systemic resistance of cucumber to Colletotrichum lagenarium. Physiol Plant Pathol, 20:73-82.

Hare, P.D.; Cress, W.A. and Van Staden, J. (2003). A regulatory role for proline metabolism in stimulating Arabidopsis thaliana seed germination. Plant Growth Regul., 39:41-50.

Hasegawa, P.; Bressan, R.A.; Zhu, J.K. and Bohnert, H.J. (2000). Plant cellular and molecular responses to high salinity.
Annu. Rev. Plant Physiol. Plant Mol. Biol., 51:463-499.

Hashish, Kh.I.; Mazhar, Azza A.M.; Zaghloul, Sahar M.; Abdel Aziz, Nahed G.; Mahgoub, Mona H. and Eid, Rawia A. (2015). Application of salicylic acid on Calendula officinalis L. is to alleviate the adverse effects of salinity stress. Int. J. Chem. Tech. Res., 8(6):379-388.

Hayat, S.; Hayat, Q.; Alyemeni, M.N.; Wani, A.S.; Pichtel, J. and Ahmad, A. (2012). Role of proline under changing environments: A review. Plant Signaling and Behavior, 7:(11):1456-1466.

Helaly, M.N.; Mohammed, Z.; El-Shaeery, N.I.; Abdelaal, Kh.A.A. and Nofal, I.E. (2017). Cucumber grafting onto pumpkin can represent an interesting tool to minimize salinity stress. Physiological and anatomical studies. Middle East Journal of Agriculture Research, 6:953975.

Hoque, M.A.; Okuma, E.; Banu, M.N.A.; Nakamura, Y.; Shimoishi, Y. and Murata, Y. (2007). Exogenous proline mitigates the detrimental effects of salt stress more than exogenous betaine by increasing antioxidant enzyme activities. J. Plant Physiology, 164(5):553-561.

Hoque, M.A.; Okuma, E.; Nakamara, Y.; Shimoishi, Y. and Murata, Y. (2008). Proline and glycinebetaine enhance antioxidant defense and methylglyoxal detoxification systems and reduce $\mathrm{NaCl}$ induced damage in cultured tobacco cells. J. Plant Physiol., 165:813-824.

Hückelhoven, R.; Fodor, J.; Preis, C. and Kogel, K.H. (1999). Hypersensitive cell death and papilla formation in barley attacked by the powdery mildew fungus are associated with hydrogen peroxide but not with salicylic acid accumulation. Plant Physiol., 119:1251-1260.

Khedr, A.H.A.; Abbas, M.A.; Wahid, A.A.A.; Quick, W.P. and Abogadallah, G.M. (2003). Proline induces the expression of salt-stress-responsive 
proteins and may improve the adaptation of Pancratium maritimum L. to saltstress. J. Exp. Bot., 54:2553-2562.

Jackson, M.L. (1967). Soil Chemical Analysis. Printice-Hall of India Private Limited, New Delhi, 498 p.

Lehmann, S.; Funck, D.; Szabados, L. and Rentsch, D. (2010). Proline metabolism and transport in plant development. Amino Acids, 39:949-962.

Malik, C.P. and Singh, M.B. (1980). Plant Enzymology and Histo-enzymology. Kalyani Publishers, India, $434 \mathrm{p}$

Mansour, M.M.F. and Ali, E.F. (2017). Evaluation of proline functions in saline conditions. Phytochemistry, 140:52-68.

Matter, F.M.A. and Abou-Sreea, A.I.B. (2016). Influence of application methods of bio-fertilization on morhological growth characters, seed yield and chemical composition of fenugreek plants. Egypt. J. Hort., 43(1):19-33.

Mostafa, Gehan G. (2015). Improving the growth of fennel plant grown under salinity stress using some biostimulants. American J. Plant Physiol., 10 (2): 77-83.

Mickky, B.M.; Abbas, M.A. and Sameh, N.M. (2019). Morpho-physiological status of fenugreek seedlings under $\mathrm{NaCl}$ stress. J. King Saud Univ., 31(4):12761282.

Nagodowithana, W.T. (1991). Yeast Technology. Universal Foods Corporation Milwaukee, Wisconsin, Published by Van Nostrsnd Reinhold New Yourk, 273 p.

Naher, N.; Uddin, M.K. and Alam, A.K.M.M. (2011). Impacts of salinity on soil properties of coastal areas in Bangladesh. J. Agri. Sci., 33(2):161-173.

Nassar, M.A. and El-Sahhar, K.F. (1998). Botanical Preparations and Microscopy (Microtechnique). Academic Bookshop, Dokki, Giza, Egypt, 219 p.
Nassar, M.A.; El-Segai, M.U. and Azoz, S.N. (2015). Influence of foliar spray with yeast extract on morhological growth characters, yield of fresh herb, anatomical structure, composition of volatile oil and seed yield components of basil Plant (Ocimum basilicum L.). Inter. J. of Advanced Res., 3(10):978-993.

Nassar, Rania M.A.; Shanan, Nermeen T. and Reda Faten, M. (2016). Active yeast extract counteracts the harmful effects of salinity stress on the growth of leucaena plant. Scientia Hort., 201:61-67.

Nofal, Fayza H.; El-Segai, M.U. and Seleem, Engy A. (2015). Response of Calendula officinalis L. plants to growth stimulants under salinity stress. AmEuras. J. Agri. \& Environ. Sci., 15 (9): 1767-1778.

Olsen, S.R. and Sommer, L.E. (1982). Phosphorus. In: Page, A.L.; Miller, R.H. and Keeney, D.R. (eds.), Methods of Soil Analysis, Part 2. Amer. Soc. Agron. Madison, Wisc., USA, pp. 403-427.

Oyiga, B.C.; Sharma, R.; Shen, J.; Baum, M.; Ogbonnaya, F.; Léon, J. and Ballvora, A. (2016). Identification and characterization of salt tolerance of wheat germplasm using a multivariable screening approach. J. Agron. Crop Sci., 202:472-485.

Rady, M.M.; Taha, R.S. and Mahdi, A.H.A. (2016). Proline enhances growth, productivity and anatomy of two varieties of Lupinus termis L. grown under salt stress. South African J. of Bot., 102: 221227.

Richards, L.A. (1954). Diagnosis and Improving of Saline and Alkaline Soils. U.S., Salinity Laboratory Staff. Agriculture Handbook, No 60.

Rigane, G.; Ben Younes, S.; Ghazghazi, H. and Ben Salem, R. (2013). Investigation into the biological activities and chemical composition of Calendula officinalis L. growing in Tunisia. Int. Food Res. J., 20(6):3001-3007. 
Roy, P.R.; Arif, M.D.T.; Polash, M.A.S.; Hossen, M.D.Z. and Hossain, M.A. (2019). Physiological mechanisms of exogenous calcium on alleviating salinity-induced stress in rice (Oryza sativa L.). Physiol. Mol. Biol. Plants, 25(3):611-624.

Sadak, Mervat Sh. and Mostafa, H.A.M. (2015). Physiological role of pre-sowing seed with proline on some growth, biochemical aspects, yield quantity and quality of two sunflower cultivars grown under seawater salinity stress. Scientia Agri., 9(1):60-69.

Sanchez, F.J.; de Andrés, E.F.; Tenorio, J.L. and Ayerbe, L. (2004). Growth of epicotyls, turgor maintenance and osmotic adjustment in pea plants (Pisum sativum L.) subjected to water stress. Field Crops Research, 86:81-90.

Siddique, A.B.; Islam, M.R.; Hoque, M.A.; Hasan, M.M.; Rahman, M.T. and Uddin, M.M. (2015). Mitigation of salt stress by foliar application of proline in rice. Universal J. of Agri. Res., 3: 81-88.

Sumanta, N.; Haque, C.I.; Nishika, J. and Suprakash,

$\mathrm{R}$.

(2014).
Spectrophotometric analysis of chlorophylls and carotenoids from commonly grown fern species by using various extracting solvents. Res. J. Chem. Sci., 4(9):63-69.

Tester, M. and Daveport, R. (2003). $\mathrm{Na}^{+}$ tolerance and $\mathrm{Na}^{+}$transport in higher plants. Annals of Bot., 91:305-327.

Tiwari, J.K.; Munshi, A.; Kumar, R.; Pandey, R.N.; Arora, A.; Bhat, J. and Sureja, A. (2010). Effect of salt stress on cucumber, $\mathrm{Na}^{+} / \mathrm{K}^{+}$ratio, osmolyte concentration, phenols, chlorophyll content. Acta Physiol. Plant, 32:103-114.

Yan, Z.; Guo, S.; Shu, S.; Sun, J. and Tezuka, T. (2011). Effects of proline on photosynthesis, root reactive oxygen species (ROS) metabolism in two melon cultivars (Cucumis melo L.) under $\mathrm{NaCl}$ stress. Afr. J. Biotechnol., 10:1838118390.

Yan, H.; Li, Q.; Park, S.C.; Wang, X.; Liu, Y.J.; Zhang, Y.G.; Tang, W.; Kou, M. and Ma, DF. (2016). Overexpression of CuZnSOD and APX enhance salt stress tolerance in sweet potato. Plant Physiol. Biochem, 109:20-27.

\section{التخفيف من آثار الإجهاد الملحي على الصفات المورفو-فسيولوجية والبيوكميائية والتشريحية لنبات الأقحوان باستخدام البرولين ومستخلص المفئو الخميرة

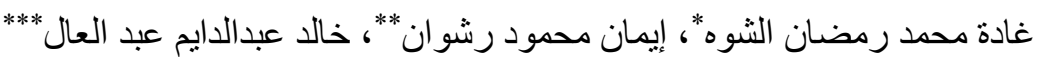

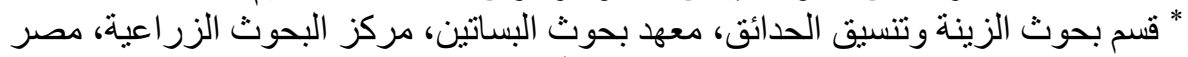

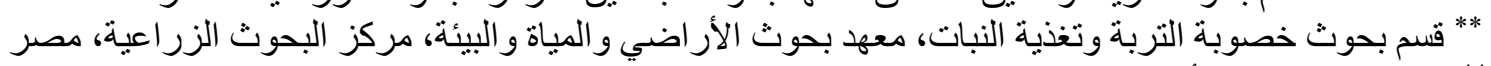

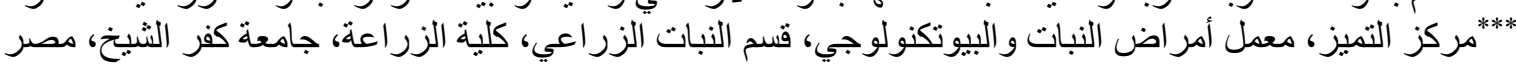

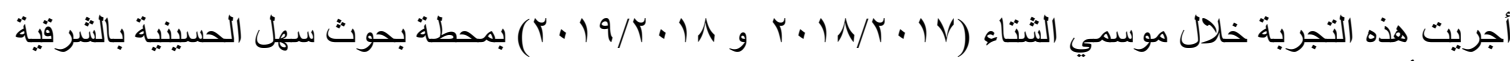

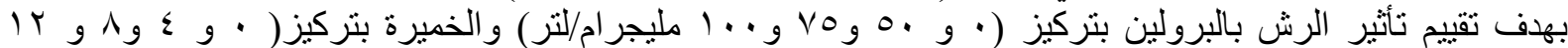

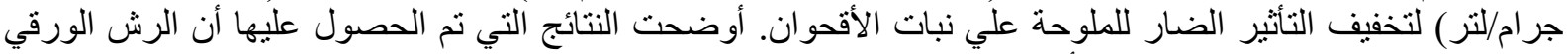

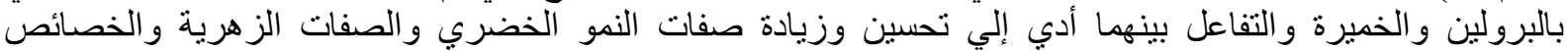

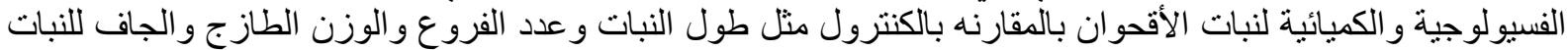

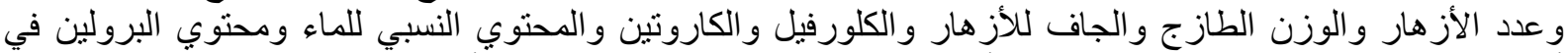

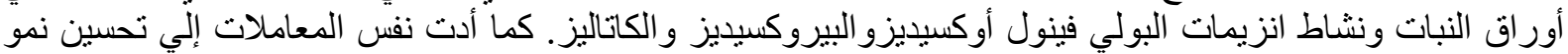

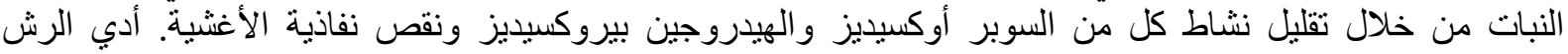

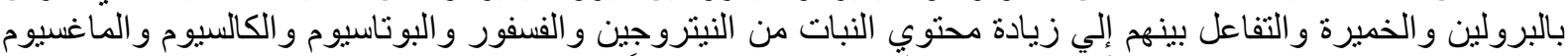

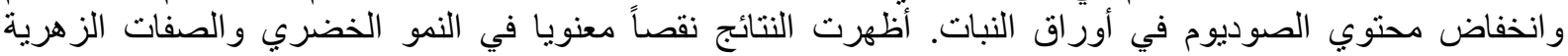




\section{Ghada M.R. El-Shawa et al.}

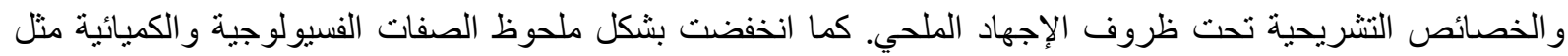

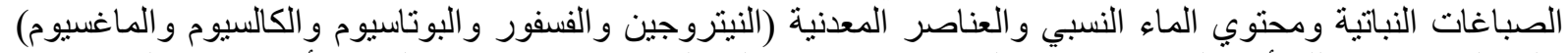

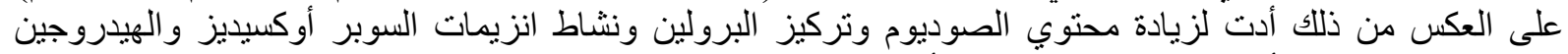

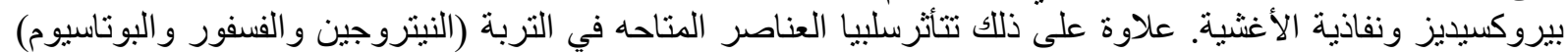

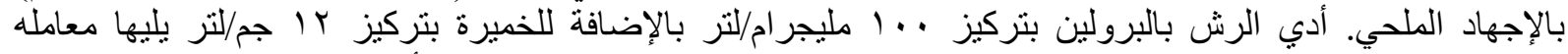

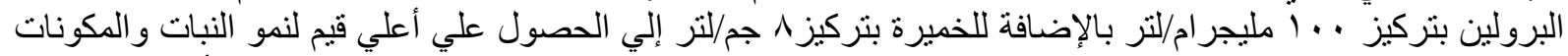

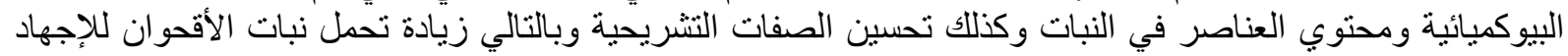

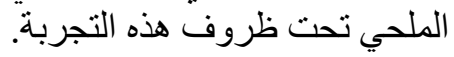

